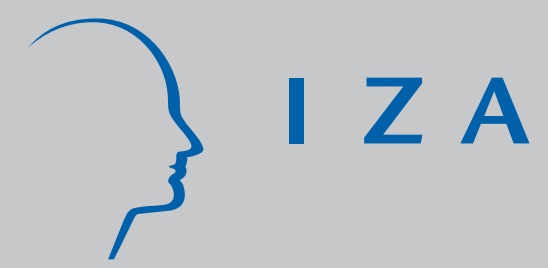

IZA DP No. 7871

Collective Bargaining and Innovation in Germany: Cooperative Industrial Relations?

John T. Addison

Paulino Teixeira

Katalin Evers

Lutz Bellmann

December 2013 


\title{
Collective Bargaining and Innovation in Germany: Cooperative Industrial Relations?
}

\author{
John T. Addison \\ University of Durham, University of South Carolina and IZA \\ Paulino Teixeira \\ University of Coimbra/GEMF and IZA \\ Katalin Evers \\ Institute for Employment Research (IAB) \\ Lutz Bellmann \\ Friedrich-Alexander-Universität Erlangen-Nürnberg, IAB and IZA
}

Discussion Paper No. 7871
December 2013

IZA
P.O. Box 7240
53072 Bonn
Germany

Phone: +49-228-3894-0

Fax: +49-228-3894-180

E-mail: iza@iza.org

\begin{abstract}
Any opinions expressed here are those of the author(s) and not those of IZA. Research published in this series may include views on policy, but the institute itself takes no institutional policy positions. The IZA research network is committed to the IZA Guiding Principles of Research Integrity.

The Institute for the Study of Labor (IZA) in Bonn is a local and virtual international research center and a place of communication between science, politics and business. IZA is an independent nonprofit organization supported by Deutsche Post Foundation. The center is associated with the University of Bonn and offers a stimulating research environment through its international network, workshops and conferences, data service, project support, research visits and doctoral program. IZA engages in (i) original and internationally competitive research in all fields of labor economics, (ii) development of policy concepts, and (iii) dissemination of research results and concepts to the interested public.
\end{abstract}

IZA Discussion Papers often represent preliminary work and are circulated to encourage discussion. Citation of such a paper should account for its provisional character. A revised version may be available directly from the author. 


\section{ABSTRACT \\ Collective Bargaining and Innovation in Germany: Cooperative Industrial Relations?}

The effect of collective bargaining on innovation has long been in dispute. At the level of theory, the hold-up problem has been used to justify positive as well as negative effects of unionism. At the empirical level, although some would consider the North American evidence as cut and dried, this is not the case for other countries. In Europe there is some suggestion that certain industrial relations systems, either alone or in combination with the regulatory framework in which they are embedded, may tip the balance in favor of a beneficial union effect. In the present paper, we assemble nationally representative data for Germany - for many observers the exemplar of a cooperative industrial relations regime - to investigate the impact of collective bargaining on (several measures of) process innovation and product innovation. Our cross section and longitudinal analysis fails to indicate that unionism retards innovation. Indeed, in conjunction with workplace representation, collective bargaining at sectoral level might even be pro innovative.

JEL Classification: J51, J53, O31

Keywords: Germany, collective bargaining, innovation

Corresponding author:

John T. Addison

Department of Economics

Moore School of Business

University of South Carolina

Columbia, SC 29208

USA

E-mail: ecceaddi@moore.sc.edu 


\section{Introduction}

The topic of collective bargaining and investment in intangible (and tangible) capital has been the subject of considerable controversy for a number of years now. The debate remains unsettled, although theory has tended to look with more favor upon the union entity if it is located in an "appropriate" institutional setting. Theory has in one sense been channelled in this direction by empirical research pointing to a sharp dichotomy between North American findings that are almost invariably negative in respect of the union impact on innovation capital and European research that generally points to an absence of significant associations once one proceeds beyond the raw correlations in the data.

In the present paper, we focus on the innovative activities of German establishments over the four-year observation window, 2007-2010. Our measure of innovation is the actual introduction of some product or process innovation. Apart from allowing us to consider a new outcome indicator, our choice of Germany was predicated on that nation's unique structure of cooperative industrial relations; early research seeming to offer some confirmation of the benefits of cooperation provided the level of union density was not "too high."

The structure of the paper is as follows. First, the theoretical backdrop receives somewhat closer attention than normal given the generalization of the hold-up principle, recent developments emphasizing specific German institutions, and the potential importance of the wider regulatory background. Next, the empirical literature on unions and innovation is reviewed. International evidence is first addressed, before proceeding to a review of contemporary research findings for Germany. There follows a discussion of our unique dataset, the Establishment Panel of the Institute for Employment Research of the Federal Employment Agency, together with some descriptive evidence on unionism and innovation. Our modelling procedure is then presented. This is followed by a detailed cet. par. analysis of the determinants of innovation and a set of difference-in-difference estimates designed to capture the causal effect of collective bargaining and worker representation on innovation. A brief summary concludes. 


\section{Theory}

Theoretical considerations suggest that collective bargaining can have positive as well as negative effects on innovation. In the traditional model, the union-set wage is represented as an exogenous change in the price of labor, with the firm duly adjusting employment along its labor demand curve. In this case, the union premium or tax is levied on labor. Union firms duly substitute away from expensive labor. The net effect is unclear. It depends on the degree of substitutability between capital and labor and the magnitude of the scale effect as the premium filters through into higher product prices and output falls.

By contrast, the more modern view is that unions tax capital, that firms respond unambiguously by cutting tangible and intangible capital investments, and that the wage is endogenous. The idea is that unions expropriate part of the quasi-rents that form part of the normal (i.e. competitive) returns to capital but which are vulnerable to capture once investment in specialized plant and equipment (and R\&D) has been made. Familiarly, such assets will continue in use as long they earn a return above their alternative use; the more specific the asset, the bigger the scope for union rent seeking. Of course, with the relation-specific capital in situ, higher wages are unlikely to influence the use of the asset, but firms will anticipate reduced returns to such capital and invest less.

This is the so-called "hold-up" problem, first analyzed by Grout (1984). Consider a simple one shot two-stage game. In the first stage, the firm chooses a level of capital (high/low) and in the next round the union chooses the wage (high/low). By backwards induction, the union will always choose a high wage in the second stage and, knowing this, the firm will always choose a low investment strategy at the first stage. As noted earlier, the union tax on investment will vary directly with the specificity of the asset and its longevity. The tax would vanish were the union able to commit itself to a low wage strategy by posting a bond or hostage to a third party, or where there was bargaining over investment as well as wages. However, neither arrangement is other than sporadically encountered in the real world. ${ }^{1}$ Now collective bargaining is repeated over time rather than being a one-shot exercise and, abstracting from an end-game scenario (Lawrence and Lawrence, 1985), repeated games offer a solution to the hold- 
up problem since opportunistic behavior can in principle be appropriately punished (e.g. van der Ploeg, 1987). An important issue in the literature has been the degree to which unions discount the future. In particular, it has been argued that because union members do not have property rights in the union they will be rationally myopic and discount the future at a higher rate than shareholders. And this tendency will be reinforced by the greater influence of older workers in union councils (Hirsch and Prasad 1995). Accordingly, much hinges in a repeated game context on the union's discount factor and the success of firms in extending the union's horizon (including greater recourse to debt), as well as inefficient defensive strategies such as the maintenance of inefficient capital or plants to facilitate substantial cuts in employment as a short-run profit-maximizing response to wage demands (for a discussion, see Baldwin, 1983).

There is a strong presumption in the unions-and-investment literature, therefore, that greater worker representation will depress investments in physical and intangible capital - the Grout result - and will be accompanied by second-best responses including greater reliance on debt financing. Abstracting from the related possibility that union firms might license out innovations rather than develop them in house - which might lead to no difference in patenting as between union and nonunion regimes - a number of theoretical caveats and new developments have also to be recognized. First, Addison and Chilton (1998) have shown that union opportunism alone does not necessarily underpin suboptimal investments in physical capital and that - irrespective of the union's horizon or the productive life of capital - sufficient patience on the part of the firm can yield self-enforcing contracts that are efficient with respect to employment and investment. In other words, the efficient outcome may depend crucially on the firm's discount factor.

Second, the hold-up model ignores the strategic component of R\&D activity. The argument here is that much $\mathrm{R} \& \mathrm{D}$ is conducted by large firms that operate in oligopolistic industries. Menezes-Filho and van Reenen (2003: 299) argue that this strategic interaction undermines the analytical clarity of the Grout result. They illustrate drawing on Ulph and Ulph's $(1994,2001)$ patent race model in which stronger unions can actually increase R\&D spending. ${ }^{2}$ 
Third, unions can help the adoption and spread of new techniques by giving workers "collective voice" (Freeman and Medoff, 1984). The labor market context is important here: it is (largely) one of continuity rather than spot market contracting because of onthe-job skills specific to the firm and the costs attaching to worker mobility and turnover. Legally protected unions can allow workers effectively to express their preferences and exercise collective voice in the shaping of internal industrial relations policies. Collective bargaining may be more effective than individual bargaining in overcoming workplace public goods problems and attendant free-rider problems. As the workers' agent, unions may facilitate the exercise of the workers' right to free speech, acquire information, monitor employee behavior, and formalize the workplace governa nce structure (see below) in such a way that better represents average workers who are more skilled. Given an appropriate response by management and a cooperative industrial relations environment, greater training, lower turnover, and better morale can help the adoption and spread of new techniques. In all these ways, unions may affect the cost of implementing technology and have an indirect effect on the price of investing in R\&D (Menezes-Filho, Ulph, and van Reenen, 1998). But there are no guarantees and the union rule book and poor industrial relations could slow down technological adoption.

Fourth, a case has also been made that unionism can facilitate efficient contracting in situations where there is a long-term relation between the two sides but where employer's ex ante promises to take workers' interests into account are not credible or where the reputation effects mechanism is weak. This characterization of the union as a commitment device was first advanced by Malcomson (1983). For their part, Freeman (1976, p. 364) and Freeman and Medoff (1984, p. 11) argue that the union governance apparatus of the collective voice model is quite consistent with the modern contracts literature. Thus, the presence of a union specializing in information about the contract and in the representation of workers can prevent employers from engaging in opportunistic behavior. Further, workers may withhold effort and cooperation when the employer cannot credibly commit to take their interests into account. Thus, fearing dismissal, workers may be unwilling to invest in firm-specific skills or disclose information facilitating pro-productive innovations at the workplace. The formation of a 
union and the introduction of a system of industrial jurisprudence is one way of protecting the employees. In this way, unions may generate worker cooperation, including the introduction of efficiency-enhancing work practices. That said, there is a downside: the threat of credible punishment implies bargaining power, the expression of which can undermine the union voice solution to the governance (and informational) problems of continuity markets.

Fifth, there is the question of how different collective bargaining structures might affect the firm's incentives to innovate - and whether the laws governing the employment relation might offset any unfavorable union or firm effects on innovation. Beginning with collective bargaining structures, the most relevant analysis is that of Haucap and Wey (2004), whose framework is that of a unionized oligopoly model with two firms that are engaged in a patent race for an innovation that lowers the labor required per unit of output (i.e. a process innovation), Innovation provides the only route for achieving a competitive edge in this setting. With the introduction of a process innovation, the investment cost of the innovation is sunk and labor's productivity rises. The size of the (specific) investment cost indexes the scale of the hold-up problem confronted by the firm under unionization. The setting is a three-stage game in which a wage-bill maximizing union sets the wage and the firm the level of employment, and where the firms compete in Cournot fashion in the product market.

But now the specific type of collective bargaining emerges as a crucial determinant of the firms' investment incentives. Haucap and Wey distinguish between three modes of unionism: decentralized, coordinated, and centralized. Decentralized bargaining is where there are two separate firm-level unions that set wages independently and noncooperatively. Coordination refers to a situation where a common, industry union sets wages separately for the two firms so as to maximize the industry wage bill. Finally, centralization refers to a common union that sets a single uniform wage standard for the two firms, again so as to maximize the industry wage bill. The model shows that firms' incentives to innovate are largest under centralization and smallest under coordination. This is because coordination permits the monopoly union to exploit its hold-up potential fully by setting discriminatory wages, while the other two union types constrain union power. Under centralization since wages are set according to average 
productivity, once a firm innovates industry productivity will rise and along with it the wage. But the wage rises less than the productivity secured by the innovation at firm level and the innovating firm will not therefore lose the entire profits. Contrast this situation with coordination, where the firm will lose all the gains of a cost-reducing innovation since the wage will rise pari passu with productivity. Finally, under decentralization, the union of the now less efficient firm makes wage concessions to restore that firm's competitiveness.

Another recent institutional application builds on employer hold-up of innovating employees - rather than the more standard worker training investments. Acharya, Baghai, and Subramanian (hereafter ABS) (2012) specify a game in which the employer first recruits an employee and chooses to invest in either an innovative or a routine project in period 0 , each requiring the same initial investment and generating cash flow at $t=2$. At $t=1$ the employee invests firm-specific effort which affects the innovative project outcome. This effort is observable but not verifiable ex ante. At time $t=1.5$ each party learns whether or not the project yielded an innovation. If the employee has invested sufficient effort, it does. The model rules out the possibility of complete contacts at $t=0$ so that at point $t=1.5$, after the employee has made the firm-specific effort and it is known that the project has generated a successful innovation, that individual is exposed to the possibility of hold-up. The employer can threaten to fire the employee to reduce the employee's bargaining power. And the innovating employee may take steps to hold on to bargaining power, prompting the employer to replace him or her with new employees. ABS now introduce a wrongful discharge law that allows the fired employee legal recourse in the event that the innovation was successful. Given the circumstances/unknowns, the parties still cannot commit to a contract that would not be renegotiated at $t=1.5$. But the law lowers the probability of employer malfeasance and increases employees' innovative efforts, thereby encouraging firms to invest in innovative projects.

If the above institutional developments modify the standard hold-up analysis, there is another German entity that also needs briefly to be addressed, namely the works council or Betriebsrat. The works council is the second component of that nation's dual system of industrial relations - the first being the system of sectoral collective 
bargaining. ${ }^{3}$ Given their location at the workplace and restricted bargaining rights, works councils are in principle the exemplary voice institutions. Indeed, Freeman and Lazear (1995) have provided a specific voice-theoretic model of the works council. Freeman and Lazear contend that the machinery of the works council holds out the prospect of an improvement in the joint surplus of the enterprise because of that body's information, consultation, and participation/co-determination rights. Having access to information that can verify management claims, the works council can render them credible to the workforce and preempt such behavior, resulting in increased effort flexibility. For its part, consultation allows new solutions to production and other workplace problems by virtue of the non-overlapping information sets of the two sides and the creativity of discussion. Finally, participation or co-determination rights generate an improvement in the joint surplus by providing workers with greater security, encouraging them to take a longer-run view of the prospects of the firm. The issue of the time horizon of workers is it will be recalled an important consideration in investment models.

Freeman and Lazear nevertheless argue that workers may be expected to demand too much involvement because their share in the joint surplus of the enterprise will continue to rise after that surplus has peaked. Equivalently, firms will either resist works councils or vest them with insufficient power. It is at this point that the wider industrial relations context in which the German works council is embedded commends itself to Freeman and Lazear because of the limits placed on their rent seeking. In particular, works councils cannot call a strike nor can they (without authorization) negotiate terms that are settled or normally settled by collective agreements at sectoral level. At issue, is whether there is a sufficient decoupling of production from distribution issues in practice, with some research suggesting that the discipline of an industry agreement makes this more likely.

\section{The Empirical Literature}

In what follows we examine the empirical literature on innovation, excluding results for tangible capital other than in passing. We begin with a brief summary of the fullest cross-country review of the unions-and-innovation literature offered by Menezes-Filho 
and van Reenen (2003) and including some early German studies. We then turn to findings from a meta regression analysis by Doucouliagos and Laroche (2013). In the light of issues raised by the latter, findings from one of the studies reviewed in section II are discussed. Finally, we provide an update of the still sparse German literature.

\section{Menezes-Filho and van Reenen (2003)}

The authors review 31 national studies on the impact of unionism along the dimensions of $R \& D$ intensity (14 studies), the output of $R \& D /$ head count of measures of innovation (5 studies), and technology diffusion/the adoption of technology (12 studies). ${ }^{4}$ First, the hallmark of the specifically R\&D studies is the divergence between the U.S. and Canadian findings on the one hand and the European evidence (for Britain and Germany) on the other. The North American studies all point towards strongly negative effects of unions on R\&D intensity, whereas the European studies suggest either insignificant effects or material non-linearities. For example two German studies by Schnabel and Wagner report no effect of union density at industry level (1992a; 1994) but a positive effect at firm level providing union density is not too high (1994). Second, studies examining the impact of union power on counts of innovations are sparse (but see below) and point in Anglo-Saxon countries to a negative but not always significant effects. The only early German study by Schnabel and Wagner (1992b) indicates positive but insignificant effects of unions (actually works councils). Third, altogether more numerous are investigations of unions and technological diffusion. The various national studies vary widely in finding. Positive raw correlations between unionism and diffusion usually become insignificant when other arguments such as wages and training enter the set of covariates. An early German study by FitzRoy and Kraft (1990) reports a negative and significant effect of unionism - or strictly 'organized labor,' namely union density interacted with works council presence - on the proportion of sales accounted for by products introduced within the previous 5 years.

\section{Doucouliagos and Laroche (2013)}

One way of organizing the data in surveys such as Menezes-Filho and van Reenen is via a meta regression analysis. One such analysis of the association between unions and innovative activity covering four countries (Canada, Germany, the United States, and the United Kingdom) is provided by Doucouliagos and Laroche (2013) who seek to 
determine the direction and magnitude of that association, establish whether there are differences between countries, and assess the contribution of differences in economic specification and measurement of the key innovation and unionization measures. The authors' meta-analysis has a basis in 27 studies providing 208 estimates (i.e. partial correlations) of the union-innovation association. The average correlation is positive for the U.K. and Germany and negative for the U.S. and Canada. To model heterogeneity in the partial correlations, the authors deploy 23 other potential explanatory variables. Apart from country dummies, these include variables reflecting data differences between the studies (e.g. whether they were conducted at industry versus firm level), a set of dummy variables picking up measurement differences in unionism and innovation, and variables reflecting differences in the controls employed in the various studies. In addition there are so-called exogenous variables - those not used in the original studies. These include time trends in the union-innovation association and the degree of labor market regulation.

Abstracting from the basic result that most of the variation in the reported estimates are attributable to differences in data used (industry versus firm), in the measurement of technology ( $R \& D$ versus patents), and in econometric specification, the key results of the meta regression exercise are fourfold. First, since none of the three non-U.S. country dummies is significant while the constant term measuring the correlation for the U.S. was negative and strongly significant, it appears that unions have a negative association with innovation across the board, contrary to the simple average correlations noted earlier. Second, the time trend is positive and significant, indicating some weakening in the adverse influence of unionism over time. Third, the coefficient on the labor regulation measure was negative indicating that in countries where labor market regulation is less onerous union effects on innovation are more adverse. ${ }^{5}$. Finally, there was some suggestion that the union effect was nonlinear; unions having a smaller impact on innovation at lower levels of union density but an elevated effect with increases in density.

\section{Acharya, Baghai, and Subramanian (2012)}

The model that wrongful discharge laws spur innovation in circumstances where the employer and the employee cannot commit to a contract that prohibits either of them 
from acting in bad faith ex post is tested using patent and financial data on 5,698 U.S. firms, 1971-1999. The base outcome indicators are the number of patents granted and the number of citations to patents. Over the sample period, U.S. courts in different states and at different times adopted three exceptions to the common law hire-at-will doctrine of which the most important was the "good faith exception" which applies when a court determines that an employer has discharged an employee in bad faith. ${ }^{6}$ The empirical model examines the before-and-after effect of a change in the law recognizing the good faith exception (inter al.) on innovative activity in affected states versus the before-andafter effect in states where no such change was introduced.

Focusing on the results for the good faith exception alone, ABS report firstly that the adoption of the good faith clause led to an increase in the annual number of patents (citations) of 12.2 (18.8) percent vis-à-vis firms in states which did not pass this law. Secondly, innovative effort as measured by patents (citations) scaled by the number of employees, or by R\&D expenditure, increased materially with the adoption of the good faith exception. Finally, the impact of the good faith exception was much stronger in innovation-intensive industries than in other industries. Although it does not consider unionism, the bottom line from this study is the finding that institutions matter - here the legal framework in which contracts are embedded. ${ }^{7}$

\section{Recent German Innovation Studies}

(a) Codetermination at the Plant Level

Studies investigating the effects of German works councils - codetermination at the plant level - have proliferated in recent years and vastly outnumber studies of the effect of collective bargaining proper. That said, innovation studies are sparse. The earliest studies of the effects of works councils involved small company samples of less than 200 establishments. Such studies examined the introduction of new products (Addison and Wagner, 1997) or R\&D expenditures (Schnabel and Wagner, 1994) and none reports statistically significant works council 'effects' on the innovation measure (other than in interaction with union density which, as noted earlier in our discussion of MenezesFilho and van Reenen (2003), points to negative effects of 'union-dominated works councils. 
In a much larger scale inquiry, using the first wave of the Hannover Firm Panel, containing information on 1,025 manufacturing plants in Lower Saxony in 1994, Addison , Schnabel, and Wagner (2001) also report an absence of association between the works council dummy and their two measures of innovative activity, namely whether or not the establishment introduced a new product or a new process in the previous year (see also Addison, Schnabel, and Wagner, 1996) Unfortunately, although the quality of the survey material is generally high, this is not the case for workplace union density where the imprecision of survey responses was too severe to exploit this question.

\section{(b) Codetermination at Company Level}

The second set of codetermination studies examine the effects of worker directors on innovation - strictly speaking the effects of the 1976 co-determination law extending quasi-parity worker representation on company supervisory boards to firms with at least 2,000 employees - on innovative activity as measured by the number of patents granted to a particular codetermined company. The major study is by Kraft, Stank, and Deventer (2011), who compare the years before the introduction of the law (specifically 1971-1976) with the period after the law became effective (1981-1990). In both time periods, the large and after 1976 the codetermined firms are compared with smaller firms. The sample comprises 148 manufacturing firms of which 61 are codetermined after 1976 and 87 are not. The authors use negative Binomial and Zero-Inflated Negative Binomial models for estimation, coupled with a fixed effects specification. The authors' regressions indicate a positive effect of codetermination at company level on firms' innovative behavior, yielding small marginal effects.

\section{The Dataset}

Our dataset is extracted from the most comprehensive establishment-level survey conducted in Germany, namely the IAB Establishment Panel (IAB-Betriebspanel). Designed to encompass a wide range of employment policy-related topics, including labor force composition and turnover (hiring and separations), wages, working hours, training, and public funding, as well as investment, innovation, and other business policies and developments, the Establishment Panel is an annual representative sample 
that currently covers some 16,000 establishments in all sectors of the economy. Most importantly for our purposes, the survey comprises a longitudinal component that is critical in our approach to identification, as described in sections V and VI. (Further details on the IAB establishment survey are to be found in Fischer et al., 2009.)

Our observation window covers the 2008-2011 surveys. In practice, however, we are looking at variables dated from 2007 up to 2010. This is because for some key arguments the relevant information collected in year $t$ pertains to year $t-1$. We do not range further back in time by reason of there being a break in the innovation measure. Specifically, prior to 2008, the questionnaire inquired of the innovation outcome in the last two years, rather than in the last year as in the 2008 though 2011 rounds.

The innovation variable is coded as a $1 / 0$ dummy variable that indicates the presence (or absence) of the selected type of innovation. The different innovation categories are defined according to the Oslo Manual guidelines (see OECD, 2005). Briefly, establishments can engage in either process or product innovation (or no such innovation). Product innovation is divided into three distinct categories: imitative, incremental, and radical, defined respectively as the introduction of a product or service that was already available from other firms in the market, an improvement to or further development of a product or service already supplied by the establishment, and the introduction of an entirely new product or service for which a new market has been created. For their part, process innovations are new procedures developed by establishments designed to improve the production process or the supply of services.

Turning to the information on the presence or otherwise of collective bargaining, the survey allows us to distinguish between firm-level agreements, industry-wide or sectoral agreements, and individual agreements between workers and firm (i.e. no collective bargaining at all). Observe that we make no attempt to use the information on orientation (i.e. whether an uncovered establishment supposedly shadows the wage settlements agreed at industry level (but see Addison et al., 2012). Nor for that matter do we look at situations in which collective agreements have recognized or implemented so-called opt-out clauses (or opening clauses) and/or company-level pacts for competitiveness. In each case, the main reason is that the relevant information is not 
observed on a yearly basis. Specifically, from the perspective of our observation window, information on pacts was collected in 2008 and 2009 but not in 2010 or in 2011, while the question on opt-out clauses was asked only in 2011. (The implications of opening clauses and pacts for competitiveness are discussed in Heinbach, 2007; Brändle and Heinbach, 2010; and Bellmann, Gerner, and Hübler, 2013.)

The raw data also contain information on the second pillar of the German dual industrial relations system: the works council. This institution is coded as a 1/0 dummy variable. We will not seek in our analysis to directly model the role of the works council on innovation since our emphasis is upon collective bargaining per se. That said, we shall of course condition innovation on the presence or otherwise of a works council. As will be explained below, this assumed exogeneity of works council presence is benign, given that establishments in our dataset rarely change their works council status over the sample period. In the interests of transparency, we chose to drop the small number of establishments that either introduced or abolished a works council (viz. 2.5 percent of the total).

Finally, we assembled a wide set of control variables from the survey. These included variables capturing the establishment's workforce structure (its skill, gender, parttime/full-time composition and type of working arrangement), together with its size, age, state of technology, ownership, single-establishment status, share of exports in sales, and expected sales development. (The full list of controls, including industry dummies, is presented in Appendix Table A.) In addition, since the survey contains information on the volume of total investments as well as the percentage of total investments allocated to the expansion of the establishment, we included the latter in our set of regressors.

In what follows, whenever possible we present separate results for manufacturing and services. Our sample is restricted to plants with at least five employees operating within the private sector of the economy. Establishments from the agricultural and extractive sectors were excluded as were plants in the public utilities. Finally, the 2009 changes in industrial classification were accommodated. In particular, since sectors in the 2007 and 2008 waves are grouped using the NACE Revision 1.1, while in 2009 and 2010 the 
classification is based on NACE Revision 2, we decided to use the latter for all establishments coded under both systems. However for establishments in waves 2007 and/or 2008 but not 2009 or 2010, we used the ad hoc procedure of the most likely transition,' on the basis of observed transitions (i.e. changes in sector classification from one system to another) for all those establishments that are coded under both systems.

\section{Preliminary Analysis}

Our actual 4-year observation window, 2007-2010, allows us to examine innovation both in cross section and longitudinally. This is an interesting starting point as we need to ensure that single- and multi-observed (i.e. panel) units are not too "distinct" from the perspective of their innovation profile.

[Table 1 near here]

At the outset, note that our variable of interest - the innovation outcome - flags whether or not an establishment has actually introduced some process or product innovation. We are therefore not considering some innovation input such as R\&D intensity. As a result, establishments are not expected to always answer in the affirmative when they are asked about innovation in the previous business year. Thus, as shown in Table 1, for those establishments that are observed in each year of the sample period, the proportion of those always responding that they have introduced, say, an incremental innovation is 27 percent $\left(=[1,200 / 4,436]^{* 100}\right)$. For those establishments observed once, twice, and three times over the same interval the proportion of similar such always-innovators is rather volatile at 48, 36, and 32 percent, respectively. In contrast, the group of establishments that have never introduced an incremental innovation makes up for 28 percent $(=1,230 / 4,436)$ of all cases in which an establishment is continually observed over the four-year span, while the corresponding proportion within the group of establishments observed once, twice, and three times is equal to 52 , 38 and 30 percent, respectively. It seems therefore that although there is a fair share of establishments for whom incremental innovation is highly persistent, it is also true that a sizeable sub-set of German establishments is strongly "disconnected" from this type of innovation. ${ }^{8}$ 
In the case of imitative innovation, the corresponding shares of always- (never-) innovators are 8, 32, 17, and 11 percent $(46,68,58$, and 49 percent) for those establishments that were, respectively, always, once, twice, and three times observed. In turn, the share of always- (never-) radical innovators are, as expected, substantially lower (higher) than those observed for imitative innovation, at, respectively, 2, 14, 5, and 3 percent $(74,86,80$, and 75 percent), respectively. The corresponding figures for process innovation are slightly larger (smaller), at 7, 28, 14, and 10 percent $(54,72,64$, and 57 percent), respectively. Finally, the proportion of always-innovators of any type, that is, the proportion of establishments that have introduced either a product (incremental, imitative or radical) or process innovation continually over the 4-year span is $34(=1,529 / 4,433)$ percent of the total number of units observed consecutively over the selected period, while for those that were observed once, twice and three times the corresponding shares are 62, 46, and 41 percent, respectively. The corresponding shares of never-innovators of any type are roughly three-fifths of those in the corresponding group of always innovators.

In sum, incremental innovation appears to be the most common type of innovation among establishments in the sample, while radical innovation is both the least common and the least continuous type of innovation. On the other hand, the incidence of product innovation is higher and more continuous than process innovation, whereas a comparison across singly-observed and panel units reveals that the share of alwaysinnovators is decreasing among those that are observed once, twice, three, and four times. This latter result implies that pure cross-section units tend to reveal a higher incidence of innovation than panel units, a pattern that is common across all types of innovation.

\section{[Table 2 near here]}

Table 2 presents the conditional and unconditional probability of innovation in the pooled data. The first row, for example, gives the unconditional probability of an establishment having introduced an innovation by type of innovation. Rows 2 through 6 give that probability conditional on works council and collective bargaining status.

Without conditioning on any other observables, it seems that works councils and collective bargaining are associated with a higher incidence of innovation of all types, 
although not exactly in the same degree. For example, the incidence of incremental innovation among establishments with (without) works councils is 65 (42) percent, while in establishments with sectoral (no collective agreement) incremental innovation occurs in 50 (47) percent of the cases. The data also suggest that firm agreements are slightly more favorable to innovation than sectoral agreements.

Disaggregating by sector - namely, manufacturing and services in panels (b) and (c) of the table - yields a similar result. That is, innovation is more often found in establishments with works councils than otherwise, while collective bargaining coverage seems more favorable to innovation and especially so in manufacturing.

Finally, although innovation is far more common in large than small establishments, much the same institutional patterns are evident in the data. In particular establishments with works councils and sectoral agreements are generally more favorable to innovation across all establishment size categories groups. (Full details are given in Appendix Table B.)

[Table 3 near here]

Table 3 presents tetrachoric correlation coefficients (that is, the correlation between any two pairs of binary variables) for our institutions and innovation measures. These statistics were obtained using a biprobit model with no covariates included in the regression. Panel (a) gives the correlations between works councils/collective bargaining and innovation, while panel (b) repeats the exercise for collective bargaining and innovation after conditioning on works council status.

Observe firstly that works councils are strongly and positively associated with innovation, while the correlation between innovation and sectoral agreements is now weaker, both in absolute terms and statistical significance. Firm-level agreements in particular appear more favorable to innovation than sectoral agreements, especially in the case of incremental and product innovation. The tetrachoric correlation conditional on specific works council-collective bargaining combinations in panel (b) suggests in turn that sectoral agreements in the absence of works councils seem to be highly unfavorable to innovation. For firm-level agreements, however, the reverse seems to be the case although statistical significance is weak. Finally, the combination of no 
collective bargaining and no works council seems more favorable to innovation than a no collective bargaining-works council combination.

These preliminary results do not control for observable, establishment-level characteristics other than the collective bargaining and worker representation institutions. We next consider whether this indicative evidence survives explicit modeling of the innovation decision.

\section{Modeling}

We model innovation in establishment $i$ in year $t, Y_{i t}$, as a function of two sets of observables, say $Z_{i t}$ and $Z_{i t}^{\prime}$, where the former vector indicates the relevant institutional categories (namely the six combinations of collective bargaining and works council status $)^{9}$ and the latter denotes other establishment characteristics, including workforce composition, export orientation, ownership, establishment size, location, and the presence of a R\&D department, inter al. (see Appendix Table A). Recall that $Y_{i t}$ is a dichotomous outcome indicating the type of innovation that establishment $i$ is carrying out in year $t$.

Our regression analysis starts with the simple (and most restrictive) pooled probit model in which all the cross-period (year) correlation is assumed away to yield:

$\operatorname{Pr}\left(Y_{i}=1 \mid X_{i}\right)=\Phi\left(X_{i} \beta\right)$,

where, to simplify the notation, $X$ denotes the full set of time-variant and time-invariant establishment-level observables, $\beta$ the set of parameters to be estimated, including the institutional interaction terms, and $\Phi$ denotes the standard normal cumulative distribution function. (In practice, model (1) treats the panel as a pure cross-section case.) In our implementation, we select the group of establishments with no sectoral agreements and no works councils as the reference category, which means that a negative sign for any of the other five institutional combinations implies that the respective institutional setting is unfavorably associated with innovation. ${ }^{\mathbf{1 0}}$

Alternatively, one can explicitly model the longitudinal dimension of the panel to obtain the random-effects probit model, given by 
$\operatorname{Pr}\left(Y_{i t}=1 \mid X_{i t}, u_{i}\right)=\Phi\left(X_{i t} \beta^{\prime}+u_{i}\right)$,

where the random effect $u_{i}$ represents the establishment's persistent unobserved traits (or its unobserved propensity to innovate) and $u_{i} \sim N\left(0, \sigma_{i}^{2}\right)$. Clearly, in this case we do not ignore the possibility that an establishment might have been observed more than once and that the innovation decision might simply be the result of the presence of some unobserved trait (or intra-establishment correlation component) that renders the outcome interdependent over time after conditioning on $X_{i t}{ }^{\mathbf{1 1}}$

An interesting aspect of model (2) is therefore that it allows us to exploit the (latent) intra-establishment correlation. This statistic is defined as $\rho=\sigma_{u}^{2} /\left(\sigma_{u}^{2}+1\right)$ and gives the correlation between any two observations in the same establishment. Based on model (2) we can also generate the manifest intra-establishment correlation, given by Pearson's $r$ coefficient, using this time the actual binary outcomes $Y_{i t}$ rather than the latent variable $Y_{i t}^{*}$ (see, for example, Rodríguez and Elo, 2003). Along with these two statistics, we will also use other measures based on actual outcomes as shown below. Taken together these statistics allow us to have a more comprehensive view of the pattern of innovation in German establishments.

Finally, we tackle establishment unobserved heterogeneity in a more direct way. This is accomplished by selecting different subsamples and looking at differences in changes in innovation over time using appropriate comparison groups. Initially, we retain only those establishments that are observed consecutively over the observation window; next we define a pre-treatment and a treatment period, say, $t_{0}$ and $t_{1}$; and, lastly, we select the comparison groups (viz. the treatment and control groups). Given that our observation window is 2007-2010, our procedure amounts to selecting 2007-2008 as the pre-treatment period (our $t_{0}$ period), and 2009-2010 as the treatment period (our $t_{1}$ period). We then focus on the group of establishments that in $t_{0}$ are not covered by a sectoral agreement and compare the innovation incidence among those establishments that have joined a collective agreement in $t_{1}$ with the innovation incidence of those that have stayed uncovered. In other words, by running the innovation variable on sectoral agreement status (both dated in $t_{1}$ ) plus some control variables to take account of potential confounding factors - either using a probit or a linear probability model - we have by construction a difference-in-differences estimate of the effect of joining a 
sectoral agreement on innovative activity. Mutatis mutandis for the effect of leaving a sectoral agreement, in which case one needs to select the subsample of establishments covered by a sectoral agreement in $t_{0}$ and again regress innovation on sectoral agreement status, both dated in $t_{1}$.

In the interests of transparency and the obligation to avoid imposing an artificial symmetry on the effects of collective bargaining on innovation, we propose to further refine the selected subsamples. In particular, we separate establishments with a revealed pattern of no innovation (in $t_{0}$ ) from those that exhibit some propensity to innovate (in $t_{0}$ ). We take an establishment that has no innovation in 2007 and 2008 to be a non-innovator, and consider as an innovator a plant that introduced an innovation in either 2007 or 2008 (or in both years). Since establishments are classified as either innovators or non-innovators (but not both), this means that we will be dealing with four different scenarios outlined in Appendix Table C. (However, in our actual implementation - in Table 6 below - we shall further identify groups of establishments with and without works councils. For expositional convenience these additional disaggregations are not shown in the appendix table.)

\section{Findings}

Table 4 presents the results from the simple pooled probit model with institutional interaction dummies (and clustered standard errors). As the first five rows of the table negatively-signed coefficients dominate - in 21 out of 30 cases the coefficient estimates are negative. A first inference, then, is that compared with the no collective bargainingno works council combination (the reference category), the presence of the two institutions - on their own or in conjunction - does not seem favorable to innovation. But the coefficients are in most cases not statistically significant; the exception being the sectoral agreements-no works council case in the second row of the table where 5 out of 6 coefficients are statistically significant (and negative). Vulgo: sectoral agreements without works councils are unlikely to be associated with a higher probability of innovation.

[Table 4 near here] 
Interestingly, the role of institutions is better (worse) determined in the limit case(s) of radical innovation (imitation), while the presence of a $R \& D$ department, training, stateof-the-art equipment, a skilled workforce, export orientation, higher expected sales, and establishment size (not separately reported in the table) are strongly favorable to (or at least positively associated with) all types of innovation. In turn, the disaggregation by sector shows that in manufacturing most coefficients are again negative and predominantly insignificant, while for services the effect of the sectoral agreement-no works council combination on innovation albeit generally negative is less pronounced than in the manufacturing sector. In contrast, sectoral agrements in conjunction with works councils seem to be slightly more favorable to innovation in services than in the case of the manufacturing sector. (Full results by sector are available upon request.)

[Table 5 near here]

The results from fitting model (2) to the data are given in Table 5. Observe firstly that despite the fact that we cannot reject the presence of the unobserved effect $u_{i}$ - or, equivalently that we can reject the simple pooled probit model (1) as a proper specification - the results are similar to those presented in Table 4. Given that the intraestablishment correlation $\rho$ is relatively small (albeit highly statistically significant), the fact that models (1) and (2) yield comparable results is not unexpected. As can be seen in the first five rows of the table, all but 7 coefficients (as compared with 9 in Table 4) are negative, while 6 are statistically significant (and negative). Similarly, the control variables maintain both their sign and statistical significance.

Based on model (2) we can also compute the manifest intra-establishment correlation (or Pearson's r), focusing in the table on the median percentile and here on the any type of innovation category. ${ }^{12}$ Pearson's $r$ is 0.37 while the joint probability (i.e. the probability of an establishment introducing any type of innovation in any two given years) is 0.39 . In turn, the corresponding marginal probability of being an innovator of any type is 0.55 , which value closely conforms with the (unconditional) probability shown in the last column of the first row of Table 2 of 0.586 , or 58.6 percent. We also computed the odds ratio, that is, the odds of an establishment introducing an innovation in, say, year $t_{0}$ and $t_{1}$ versus not introducing an innovation in $t_{0}$ but in $t_{1}$. Not altogether unexpectedly, the odds ratio is relatively high, at 4.76, meaning that it is more likely for an innovator to stay as an innovator than a non-innovator joining the group of 
innovators. This result confirms the non-negligible persistence in both innovation and non-innovation.

\section{[Table 6 near here]}

Table 6 presents our DiD estimates of the effect of joining/leaving a sectoral agreement on innovation. As described in the modeling section, in this case we require all included establishments to be observed consecutively over the period 2007-2010. On the other hand, the four yearly observations are by construction collapsed to a single cloud of data, meaning that we end up with a much smaller number of observations than in Tables 4 and 5. Moreover, as reported in Appendix Table $\mathrm{C}$, the selection of relevant subsamples implies a further reduction in sample size. We have therefore to focus exclusively on sectoral agreements and upon a single outcome, given by the 'any type of innovation' composite. For the same reasons, we have to forego reporting results for manufacturing and services.

The estimates in Table 6 are from two different implementations: the probit model in the penultimate column and the linear probability model in the final column of the table. Given that our empirical strategy involves a sizable reduction in the estimation sample, we decided to run these two models for checking purposes. (The linear probability model is less computationally demanding and indeed implies a slight increase in the number of observations.) Comparing the last two columns in the table, it is quite striking that they yield virtually the same estimates, while the non-joint significance of all included regressors in the probit case, given by the Wald $\chi^{2}$ statistic, is rejected at the .05 level or better in four out of six cases. We note parenthetically that in two cases out of the eight in the penultimate column of the table the estimation sample is too small to permit estimation.

The critical finding, however, is that only in one case do we find a statistically significant causal effect of sectoral agreements on the innovation outcome. As shown by the negative coefficient in the last row of the table, leaving a sectoral agreement in the presence of a works council decreases the probability of innovation in either 2009 and 2010 (or in both years) for an establishment that had introduced some type of innovation in either 2007 and 2008 (or in both years). What this result suggests is that the combination of sectoral agreements with works councils is more favorable to 
innovation than the no sectoral agreements-works council combination, a result that confirms our preliminary findings in Table 3. In turn, the lack of statistical significance on almost all treatment effects across the eight rows in Table 6 implies that collective bargaining does not seem to impair innovation to any discernible degree in Germany.

For completeness, we also ran a different version of the model implemented in Table 6. In this case, we selected separate samples of non-innovating and innovating establishments in combination with the sectoral agreement transition groups, but now without conditioning on works council status in $t_{0}$. The main goal here was to obtain a larger sample. To illustrate, given both non-innovator status and absence of sectoral agreement coverage in $t_{0}$, we ran the innovation variable on sectoral agreement status (both dated in $t_{1}$ ) first with and then without a works council variable in the regression. (The treatment and control groups are exactly the same as in the penultimate column of Table 6, cases 1 through 4.) The results from this exercise are given in Appendix Table D and provide no analytical gain. In no case is there evidence of a statistically significant causal relationship between sectoral agreements and innovation.

[Table 7 near here]

As a final exercise, Table 7 shows an alternative route in which we selected the relevant subsamples of innovators and non-innovators but this time interacting the sectoral collective bargaining joiner and never member dummies with the works council variable - and similarly for the sectoral collective bargaining leaver and always member arguments. Taking sectoral collective bargaining leavers versus always members in the sample of non-innovators, for example, the exercise amounts to pooling case 2 in the second and fourth rows of Table 6 and setting sectoral collective bargaining leavers-no works council as the as the control group (the reference category). Clearly, the presumption behind Table 7 is that all establishments with collective agreements in $t_{0}$ are comparable, irrespective of whether they have a works council or not. In other words, our implicit assumptions in Table 7 are stronger than those in Table 6, although the exercise allows us to test an additional hypothesis: are sectoral collective bargaining leavers in a comparatively better position with respect to innovation when a works council is present? As can be seen from the table, the sectoral collective bargainingworks council interaction term shown is positive and highly significant. Given the comparison group (viz. the sectoral collective bargaining leaver-no works council 
category), it follows that leaving sectoral agreements is less favorable to innovation in circumstances where the plant does not have a works council. All the other interaction terms lack statistical significance.

By way of summary, our descriptive analysis shows that the profile of innovators and non-innovators alike has considerable persistence over time. In turn, the regressions on the pooled data suggest that the impact of the two institutions of collective bargaining and worker representation on innovation is not dramatic. The exception is of course the sectoral agreements-no works council combination which appears less favorable to innovation than an alternative combination of no-collective agreement and no works council.

Perhaps not surprisingly, the evidence based on difference-in-difference estimates is less clear-cut as the exercise requires that the included establishments be observed over a period of four consecutive years, a rather demanding data requirement. Our DiD approach also implied a further diminution in estimation sample as we sought to increase the number of meaningful comparisons across treatment and control groups. The limitations of this empirical approach notwithstanding, it does not appear to be the case that establishments materially influence innovation with the decision to leave (join) sectoral agreements as compared with those that decide to stay put, that is remain covered (uncovered). Nor is it plausible to suppose that leaving a sectoral agreement when there is no works council present is more favorable to innovation than the situation where a works council is present.

\section{Conclusions}

This study seeks to provide a thorough analysis of the effect of collective bargaining on innovation using both cross-section and longitudinal evidence extracted from a nationally representative set of German establishments. Since the theory is inconclusive regarding the impact of collective bargaining on innovation - but of late allowing more scope for country-specific institutions to play a positive role in influencing outcomes - it is appropriate to reinvestigate an exemplar of cooperative industrial relations using a 
rich dataset combining institutional arrangements on the one hand and observes and unobserved individual (establishment) traits on the other.

We conclude that there is no dramatic impact of collective bargaining agreements on innovation for Germany as has been reported for North America. Rather, all is rather quiet on this particular front. The long-standing tradition of industry-wide agreements has not disrupted the observed pattern of innovative activity.

However, not all establishments are innovators and innovating establishments are not always cast in that role. Instead one is struck by the seeming stable attitude towards innovation, one that renders innovation to a large extent independent of changes in collective bargaining status. By the same token, nor do we find that the presence of collective bargaining actually enhances innovation either.

Unlike the North American evidence, therefore, bargaining Sturm und Drang in innovation behavior is contraindicated. Collective bargaining cannot be construed as inhibiting innovation. Indeed, in conjunction with worker representation entities, it can even be more innovative than otherwise. 


\section{Footnotes}

1. We ignore for the moment the potential hold-up problem on the part of the employer.

2. The context is a Cournot duopoly model in which separate, firm-specific unions bargain ex post (i.e. there is no bargaining over R\&D in the first stage) over wages and employment. Provided the union places sufficient weight on employment vis-à-vis wages, an increase in union bargaining power can be shown to promote employment and lead to higher market share. The firm is then supposed to raise its investment in $\mathrm{R} \& \mathrm{D}$ so as to protect this enhanced market share.

3. Works councils are the expression of codetermination at workplace level. Codetermination is also practised at company or enterprise level, where for practical purposes it can be equated with worker directors. Space constraints pre-empt a theoretical discussion of worker board level representation but empirical findings of innovation activity under quasi-parity representation are provided in section III. The rights and responsibilities of each codetermination body are given in Addison (2009.).

4. The authors also investigate productivity growth (13 studies).

5. Experimentation with an employment protection index also suggested that heightened employment protection yielded smaller negative correlations.

6. The other two exceptions in descending order of importance are the public policy exception protecting whistleblowers, and the implied-contract exception where the employer implicitly signals that termination shall be by just cause.

7. A yet to be resolved issue, however, is the relationship of these findings with those of other studies pointing to adverse effects of employment protection legislation and wrongful discharge procedures in particular in lowering employment and distorting production choices (see Autor, Donohue, and Schwab, 2006; Autor, Kerr, and Kugler, 2007).

8. The analysis of the intra-establishment correlation, or the correlation between innovation in year $t$ and innovation in year $t+\tau$ requires some specific modeling and is left to section VI below.

9. The total of six interaction terms comes from the combination of collective bargaining presence (sectoral agreement, firm-level agreement, or no collective bargaining at all) and the presence (or absence) of a works council. By introducing these interaction terms, we avoid dealing directly with any possible endogeneity between works councils and collective agreement (see Gartner, Schank, and Schnabel, 2010, for a similar approach). In any event, since we will ultimately rely on longitudinal evidence, simultaneity issues are substantially reduced as council status seldom changes over time while transitions in collective bargaining status at establishment level are frequent by comparison.

10. At this stage we do not model the possibility of some underlying establishment traits simultaneously determining industrial relations status and the outcome (innovation). 
11. If this interdependence is sufficiently strong, any association between, say, sectoral agreements with works councils and innovation, as captured in a pure pooled probit analysis, may be simply the result of strong establishment-specific inertia in the innovation process that just happens to be associated with that particular combination of institutions rather than having any causal content.

12. All the statistics based on actual outcomes are obtained using the xtrho command in Stata. The full set of results is available on request. 


\section{References}

Acharya, Viral. V., Ramin P. Baghai, and Krishnamurthy V. Subramanian. 2012. "Wrongful Discharge Laws and Innovation." NBER Working Paper No. 18516. Cambridge MA: National Bureau of Economic Research, November.

Addison, John T. 2009. The Economics of Codetermiantion: Lessons from the German Experience. New York: Macmillan Palgrave.

Addison, John T., and John Chilton. 1998. "Self-Enforcing Union Contracts: Efficient Investment and Employment." Journal of Business, Vol. 71, No. 3, pp. 349-69.

Addison, John T. and Joachim Wagner. 1997. "The Impact of German Works Councils on Profitability and Innovation: New Evidence from Micro Data." Jahrbücher für Nationalökonomie und Statistik, Vol. 216, No. 1, pp. 1-20.

Addison, John T., Claus Schnabel, and Joachim Wagner. 1996. “German Works Councils, Profits and Innovation." Kyklos, Vol. 49, No.4, pp. 555-582.

Addison, John T., Claus Schnabel, and Joachim Wagner. 2001. "Works Councils in Germany: Their Effects on Establishment Performance." Oxford Economic Papers, Vol. 53, pp. 659-694.

Addison, John T., Paulino Teixeira, Katalin Evers, and Lutz Bellmann. 2012. "Is the Erosion Thesis Overblown? Evidence from the Orientation of Uncovered Employers." IZA Discussion Paper No. 6658. Bonn: Institute for the Study of Labor/Forschungsinstitut zur Zukunft der Arbeit.

Autor, David H., William R. Kerr, and Adriana D. Kugler, 2007. "Does Employment Protection Reduce Productivity? Evidence from U.S. States.” Economic Journal, Vol. 117, No. 521, pp. F189-F217.

Autor, David H., John J. Donahue III, and Stewart J. Schwab. 2006. "The Costs of Wrongful Discharge Laws." Review of Economics and Statistics, Vol. 88, No. 2, pp. 211-231.

Baldwin, Carliss Y. 1983. "Productivity and Labor Unions: An Application of the Theory of Self-Enforcing Contracts.” Journal of Business, Vol. 56, No. 2, pp. 155-85.

Bellmann, Lutz, Hans-Dieter Gerner, and Olaf Hübler. 2013. "Investnment Under Company Level Pacts." IZA Discussion Paper No, 7195. Bonn: Institute for the Study of Labor/Forschungsinstitut zur Zukunft der Arbeit. (Forthcoming in Economic and Industrial Demomocracy.)

Brändle, Tobias, and Wolf Dieter Heinbach. 2013. "Opening Clauses in Collective Bargaining Agreements: More Flexibility to Save Jobs? Review of Economics, Vol. 64, No. 2, pp. 159-192.

Doucouliagos, Hristos, and Patrice Laroche. 2013. "Unions and Innovation: New Insights From the Cross-Country Evidence.” Industrial Relations, Vol. 52, No. 2, pp. 467-491. 
Fischer, Gabriele, Florian Janik, Dana Müller, and Alexandra Schmucker. 2009. "The IAB Establishment Panel: Things Users Should Know." Schmollers Jahrbuch Vol. 129, No. 1, pp. 133-148.

FitzRoy, Felix, and Kornelius Kraft. 1990. "Innovation, Rent-Sharing and the Organization of Labor in the Federal Republic of Germany." Small Business Economics, Vol. 2, No. 4, pp. 95-103.

Freeman, Richard B. 1976. "Individual Mobility and Union Voice in the Labor Market." American Economic Review, Papers and Proceedings, Vol. 66, No. 2, pp. 361-368.

Freeman Richard B., and James L. Medoff. 1984. What Do Unions Do? New York, NY: Basic Books.

Freeman, Richard B., and Edward P. Lazear. 1995. "An Economic Analysis of Works Councils." In Joel Rogers and Wolfgang Streeck (eds.), Works Councils: Consultation, Representation and Cooperation in Industrial Relations. Chicago, IL: University of Chicago Press, pp. 27-52.

Gartner, Hermann, Thorsten Schank, and Claus Schnabel. 2010. "Wage Cyclicality under Different Regimes of Industrial Relations.” IZA Discussion Paper No. 5228. Bonn: Institute for the Study of Labor/Forschungsinstitut zur Zukunft der Arbeit.

Grout, Paul A. 1984. "Investment and Wages in the Absence of Binding Contracts: A Nash Bargaining Approach.” Econometrica, Vol. 46, No. 2, pp. 449-60.

Haucap, Justus, and Christian Wey. 2004. "Unionisation Structures and Innovation Incentives." Economic Journal, Vol. 114, No. 494, pp. C149-C165.

Heinbach, Wolf Dieter. 2007. "Wages in Wage-Setting Regimes with Opening Clauses." AStA -Wirtschafts- und Sozialstatistisches Archiv, Vol. 21, No. 3, pp. 233-245.

Hirsch, Barry T. and Kislaya Prasad. 1995. "Wage-Employment Determination and a Union Tax on Capital: Can Theory and Evidence Be Reconciled?" Economics Letters, Vol. 48, No. 1, pp. 61-71.

Kraft, Kornelius, Jörg Stank, and Ralf Dewenter. 2011. "Co-determination and Innovation." Cambridge Journal of Economics, Vol. 35, No. 1, pp. 145-172.

Lawrence, Colin, and Robert Z. Lawrence. 1985. "Manufacturing Wage Dispersion: An End Game Interpretation." Brookings Papers on Economic Activity, Vol. 1, pp. 4-116.

Malcomson, James M. 1983. "Trade Unions and Economic Efficiency." Economic Journal, Vol. 93, No. 369, pp. 51-65.

Menezes-Filho, Naercio, David Ulph, and John van Reenen. 1998. "R\&D and Unionism: Comparative Evidence from British Companies and Establishments." Industrial and Labor Relations Review, Vol. 52, No. 1, pp. 45-63. 
Menezes-Filho, Naercio, and John Van Reenen. 2003. "Unions and Innovation: A Survey of the Theory and Empirical Evidence." In John T. Addison and Claus Schnabel, eds., International Handbook of Trade Unions. Cheltenham, England, and Northampton MA: Edward Elgar, pp. 293-334.

Schnabel, Claus, and Joachim Wagner. 1992a. "Unions and Innovative Activity in Germany." Journal of Labor Research, Vol. 13, No. 8, pp. 393-406.

Schnabel, Claus, and Joachim Wagner. 1992b. "Unions and Innovations: Evidence from German Micro Data.” Economics Letters, Vol. 39, No. 3, pp. 369-373.

Schnabel, Claus, and Joachim Wagner. 1994. "Industrial Relations and Trade Union Effects on Innovation in Germany.” Labour, Vol. 8, No. 3, pp. 489-503.

OECD. 2005. Oslo Manual: Guidelines for Collecting and Interpreting Innovation Data.. Paris: Organisation for Economic Co-operation and Development.

Rodríguez, Germán, and Irma Elo, 2003. "Intra-class Correlation in Random-Effects Models for Binary Data.” The Stata Journal, Vol. 3, No. 1, pp. 32-46.

Ulph, Alistair M., and David T. Ulph. 1994. "Labour Markets and Innovation: Ex Post Bargaining.” Europeann Economic Review, Vol. 38, No. 3-5, pp. 195-210.

Ulph, Alistair M., and David T. Ulph. 2001. "Strategic Innovation with complete and Incomplete Labour Market Contracts." Scandinavian Journal of Economics, Vol. 103, No.2, pp. 1465-1492.

van der Ploeg, Frederick. 1987. "Trade Unions and Investment: A Noncooperative Approach." European Economic Review, Vol. 31, No. 4, pp. 1465-1492. 
Table 1

Innovation in Germany, all establishments with at least five employees in the private sector, 2007-2010

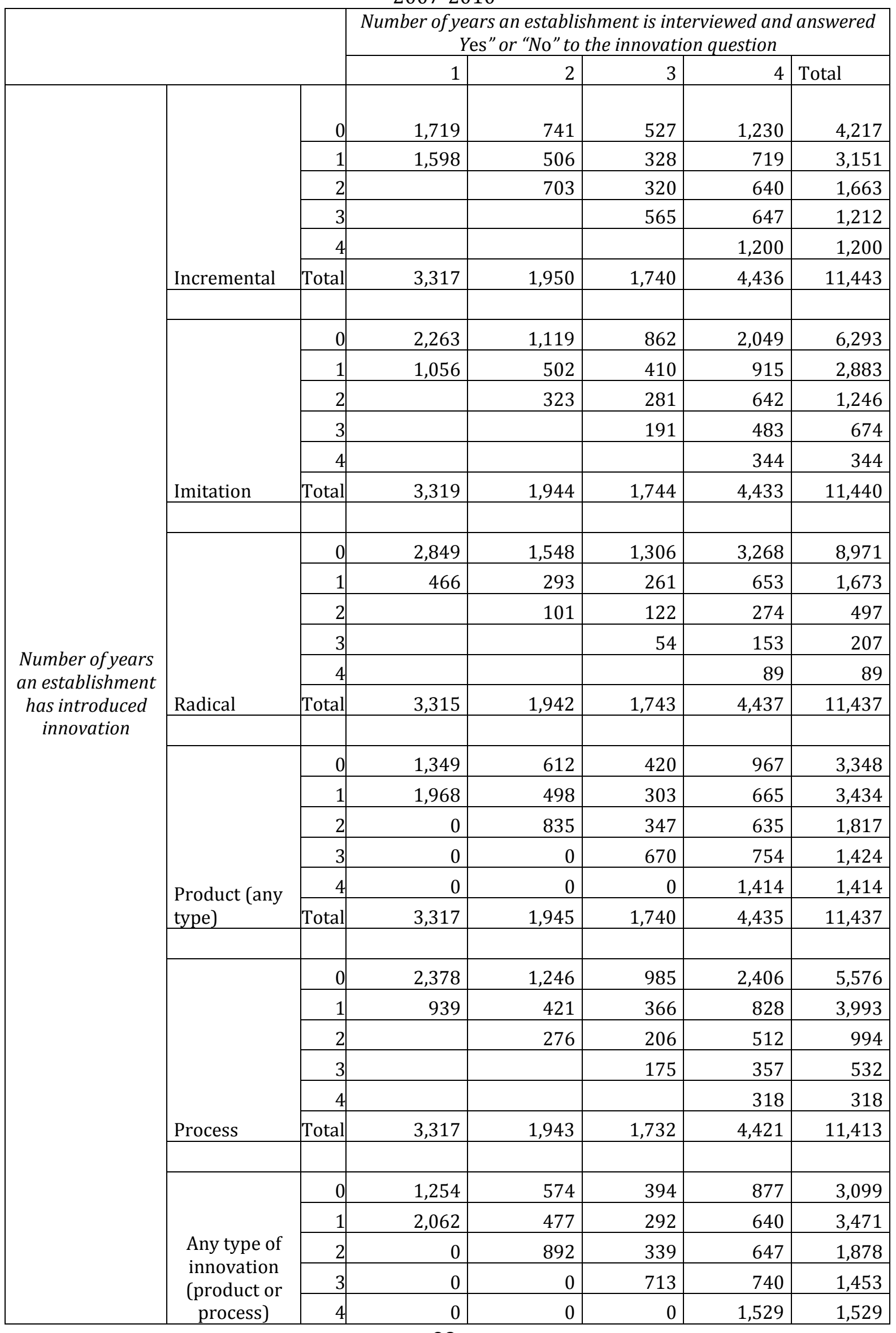




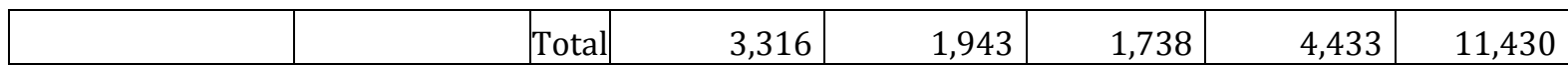

Notes: Innovation is a 1/0 dummy variable defined as equal to 1 if an establishment reports having introduced the given type of innovation in the previous year, 0 otherwise. The first cell in the table, for example, indicates out of 3,317 establishments observed only once over the selected time span, 1,719 claimed not to have introduced an incremental innovation. The corresponding row total indicates that 4,217 establishments (out of a total of 11,443 establishments) did not introduce any incremental innovation at all. The reported results are based on the IAB establishment survey, 2008-2011 waves. 
Table 2

Sample innovation incidence in Germany, all establishments with at least five employees in the private sector, and manufacturing and services, 2007-2010 (in percent)

\begin{tabular}{|c|c|c|c|c|c|c|}
\hline & \multicolumn{6}{|c|}{ Type of innovation } \\
\hline & incremental & imitation & radical & product & process & any type \\
\hline \multicolumn{7}{|l|}{ (a) Private sector } \\
\hline$P()$. & 49.8 & 29.0 & 12.1 & 56.2 & 24.7 & 58.6 \\
\hline$P(. \mid$ woco $=0)$ & 41.7 & 25.3 & 9.2 & 48.4 & 17.7 & 50.6 \\
\hline$P(. \mid$ woco $=1)$ & 64.5 & 34.1 & 16.2 & 69.6 & 36.3 & 72.0 \\
\hline $\mathrm{P}(. \mid \mathrm{cb}$ _status=scb) & 49.4 & 28.5 & 11.4 & 55.4 & 24.8 & 57.5 \\
\hline$P(. \mid c b$ _status=fcb) & 58.2 & 30.8 & 12.6 & 62.6 & 30.6 & 64.9 \\
\hline $\mathrm{P}(. \mid \mathrm{cb}$ _status=nocb) & 47.3 & 27.5 & 11.4 & 53.9 & 21.7 & 56.4 \\
\hline \multicolumn{7}{|l|}{ (b) Manufacturing } \\
\hline$P()$. & 63.6 & 33.9 & 17.5 & 68.5 & 34.2 & 71.2 \\
\hline$P(. \mid$ woco $=0)$ & 52.8 & 29.9 & 13.7 & 58.8 & 23.8 & 61.7 \\
\hline $\mathrm{P}(. \mid$ woco $=1)$ & 76.1 & 37.0 & 21.0 & 79.3 & 45.0 & 81.7 \\
\hline $\mathrm{P}(. \mid \mathrm{cb}$ _status=scb) & 68.9 & 34.3 & 19.1 & 72.9 & 39.7 & 75.2 \\
\hline$P(. \mid c b$ _status=fcb) & 72.0 & 36.8 & 16.3 & 74.7 & 37.9 & 77.4 \\
\hline $\mathrm{P}(. \mid \mathrm{cb}$ status=nocb) & 57.5 & 31.6 & 15.6 & 63.3 & 28.1 & 66.2 \\
\hline \multicolumn{7}{|l|}{ (c) Services } \\
\hline$P()$. & 48.9 & 24.7 & 9.2 & 53.2 & 23.1 & 55.7 \\
\hline$P(. \mid$ woco $=0)$ & 44.2 & 21.9 & 7.9 & 48.6 & 19.2 & 51.0 \\
\hline $\mathrm{P}(. \mid$ woco=1) & 60.1 & 29.9 & 10.7 & 63.8 & 30.8 & 66.0 \\
\hline $\mathrm{P}(. \mid c b$ _status=scb) & 47.7 & 25.9 & 7.8 & 52.2 & 22.3 & 54.6 \\
\hline $\mathrm{P}(. \mid \mathrm{cb}$ _status $=\mathrm{fcb})$ & 50.7 & 23.9 & 8.9 & 53.9 & 25.6 & 55.5 \\
\hline $\mathrm{P}(. \mid \mathrm{cb}$ _status=nocb) & 48.3 & 22.4 & 9.1 & 52.4 & 21.5 & 54.9 \\
\hline
\end{tabular}

Notes: P(.) gives the sample probability (or the standardized proportion) of a given innovation type. It is obtained by dividing the number of cases in which an establishment reported having introduced a given type of innovation by the total number of cases observed. The conditional proportion $\mathrm{P}($.|woco $=0)$, for example, gives the proportion of establishments that introduced a given innovation among the subset of establishments without a works council. $\mathrm{P}\left(. \mid \mathrm{cb}_{-}\right.$status=scb) is the corresponding probability within the subset of establishments covered by a sectoral agreement. Note also that the sectoral (firm-level) agreement dummy is equal to 0 if and only if there is no firm-level (sectoral) agreement. 
Table 3

Tetrachoric correlation between innovation and selected combinations of works council and collective bargaining presence, all establishments with at least five employees in the private sector, 2007-2010

\begin{tabular}{|c|c|c|c|c|c|c|c|}
\hline \multirow{2}{*}{\multicolumn{2}{|c|}{$\begin{array}{c}\text { Works council and } \\
\text { collective bargaining } \\
\text { presence }\end{array}$}} & \multicolumn{6}{|c|}{ Type of innovation } \\
\hline & & incremental & imitation & radical & product & process & any type \\
\hline \multicolumn{8}{|l|}{ (a) } \\
\hline \multicolumn{2}{|c|}{ Works council } & $0.343 * * *$ & $0.156 * * *$ & $0.209^{* * *}$ & $0.324 * * *$ & $0.342^{* * *}$ & $0.333^{* * *}$ \\
\hline \multicolumn{2}{|c|}{ Sectoral agreement } & $0.034 \quad * * *$ & $0.019 *$ & 0.002 & $0.023^{* *}$ & $0.064^{* * *}$ & 0.017 \\
\hline \multicolumn{2}{|c|}{ Firm-level agreement } & $0.148^{* * *}$ & $0.053^{* * *}$ & 0.033 & $0.119^{* * *}$ & $0.149^{* * *}$ & $0.118^{* * *}$ \\
\hline \multicolumn{2}{|c|}{ No collective agreement } & $-0.057^{* * *}$ & $-0.026^{* * *}$ & $-0.008^{* *}$ & $-0.042^{* * *}$ & $-0.083^{* * *}$ & $-0.037^{* * *}$ \\
\hline \multicolumn{8}{|l|}{ (b) } \\
\hline \multirow{2}{*}{$\begin{array}{l}\text { Sectoral } \\
\text { agreement }\end{array}$} & $\begin{array}{l}\text { Works } \\
\text { council }\end{array}$ & $0.050 \quad * * *$ & 0.014 & 0.038 & 0.028 & $0.071^{* * *}$ & 0.009 \\
\hline & $\begin{array}{l}\text { No works } \\
\text { council }\end{array}$ & $-0.143 * * *$ & $-0.060 * * *$ & $-0.164 \quad * * *$ & $-0.135^{* * *}$ & $-0.145^{* * *}$ & $-0.139 * * *$ \\
\hline \multirow{2}{*}{$\begin{array}{l}\text { Firm-level } \\
\text { agreement }\end{array}$} & $\begin{array}{l}\text { Works } \\
\text { council }\end{array}$ & 0.008 & -0.014 & $-0.062 *$ & -0.026 & 0.023 & -0.041 \\
\hline & $\begin{array}{l}\text { No works } \\
\text { council }\end{array}$ & 0.045 ** & 0.001 & 0.008 & 0.021 & 0.040 & 0.016 \\
\hline \multirow{2}{*}{$\begin{array}{l}\text { No collective } \\
\text { agreement }\end{array}$} & $\begin{array}{l}\text { Works } \\
\text { council }\end{array}$ & $-0.039 * *$ & -0.007 & -0.017 & -0.015 & $-0.059^{* * *}$ & 0.002 \\
\hline & $\begin{array}{l}\text { No works } \\
\text { council }\end{array}$ & 0.122 *** & $0.053 * * *$ & $0.143 \quad * * *$ & 0.118 *** & $0.122^{* * *}$ & $0.123^{* * *}$ \\
\hline
\end{tabular}

Notes: The reported coefficients - which give the correlations between pairs of binary variables - are obtained using a biprobit model with no regressors. The works council and collective bargaining variables are dummies defined as equal to 1 if the institution is present and 0 if it is not present. $* * *$, and $* * *$ denote statistical significance at the $0.1,0.05$, and 0.01 , levels, respectively. 
Table 4

Probit estimates of the determinants of innovation in Germany, all establishments with at least 5 employees in the private sector, 2007-2010

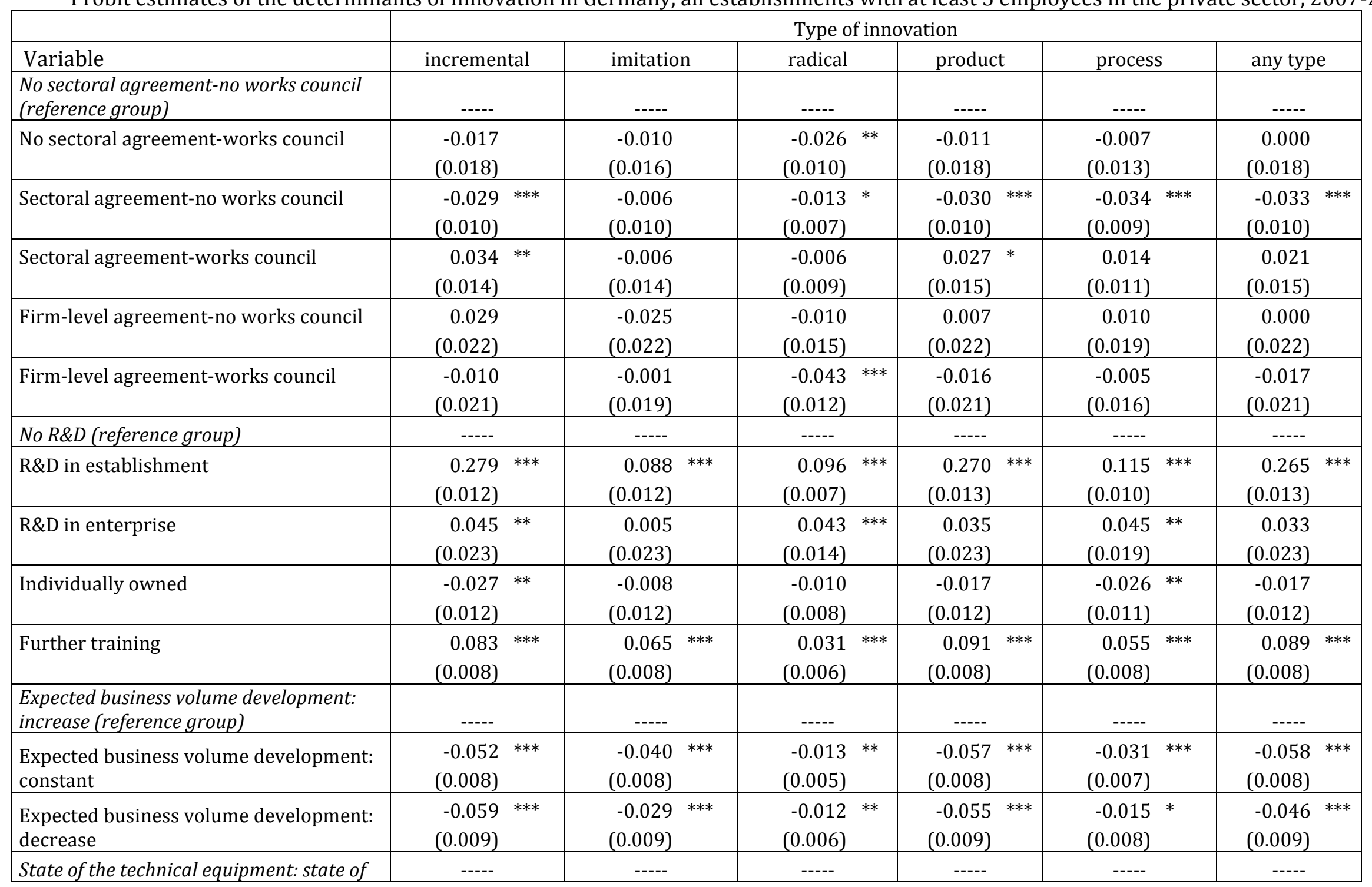




\begin{tabular}{|c|c|c|c|c|c|c|c|c|c|c|c|}
\hline art (reference group) & & & & & & & & & & & \\
\hline $\begin{array}{l}\text { State of the technical equipment: rather } \\
\text { new }\end{array}$ & $\begin{array}{r}-0.025 \\
(0.009) \\
\end{array}$ & $* * *$ & $\begin{array}{r}-0.019 \\
(0.009) \\
\end{array}$ & & $\begin{array}{r}-0.015^{* *} \\
(0.006)\end{array}$ & $\begin{array}{r}-0.017 \\
(0.010) \\
\end{array}$ & & $\begin{array}{r}-0.052 \\
(0.008) \\
\end{array}$ & $* * *$ & $\begin{array}{r}-0.024 \\
(0.010) \\
\end{array}$ & \\
\hline $\begin{array}{l}\text { State of the technical equipment: medium } \\
\text { or worse }\end{array}$ & $\begin{array}{r}-0.069 \\
(0.011)\end{array}$ & $* * *$ & $\begin{array}{r}-0.035 \\
(0.011)\end{array}$ & $* * *$ & $\begin{array}{r}-0.028 * * * \\
(0.007)\end{array}$ & $\begin{array}{r}-0.052 \\
(0.011)\end{array}$ & $* * *$ & $\begin{array}{r}-0.083 \\
(0.009)\end{array}$ & $* * *$ & $\begin{array}{r}-0.058 \\
(0.011)\end{array}$ & $* * *$ \\
\hline Share of part-time workers & $\begin{array}{r}0.000 \\
(0.000) \\
\end{array}$ & & $\begin{array}{r}0.001 \\
(0.000) \\
\end{array}$ & $* * *$ & $\begin{array}{r}0.000 * \\
(0.000)\end{array}$ & $\begin{array}{r}0.000 \\
(0.000) \\
\end{array}$ & & $\begin{array}{r}0.000 \\
(0.000) \\
\end{array}$ & & $\begin{array}{r}0.000 \\
(0.000) \\
\end{array}$ & \\
\hline Share of fixed-term contract workers & $\begin{array}{r}0.000 \\
(0.000) \\
\end{array}$ & & $\begin{array}{r}0.000 \\
(0.000) \\
\end{array}$ & & $\begin{array}{r}0.000 \\
(0.000) \\
\end{array}$ & $\begin{array}{r}0.000 \\
(0.000) \\
\end{array}$ & & $\begin{array}{r}0.000 \\
(0.000) \\
\end{array}$ & & $\begin{array}{r}0.000 \\
(0.000) \\
\end{array}$ & \\
\hline Share of high-skilled workers & $\begin{array}{r}0.002 \\
(0.000) \\
\end{array}$ & $* * *$ & $\begin{array}{r}0.001 \\
(0.000) \\
\end{array}$ & $* * *$ & $\begin{array}{r}0.001 \\
(0.000)\end{array}$ & $\begin{array}{r}0.001 \\
(0.000) \\
\end{array}$ & $* * *$ & $\begin{array}{r}0.000 \\
(0.000)\end{array}$ & & $\begin{array}{r}0.001 \\
(0.000) \\
\end{array}$ & $* * *$ \\
\hline Single-establishment & $\begin{array}{r}-0.025 \\
(0.010) \\
\end{array}$ & $* *$ & $\begin{array}{r}-0.041 \\
(0.009) \\
\end{array}$ & $* * *$ & $\begin{array}{r}-0.013 \text { ** } \\
(0.006)\end{array}$ & $\begin{array}{r}-0.035 \\
(0.010) \\
\end{array}$ & $* * *$ & $\begin{array}{r}-0.033 \\
(0.008) \\
\end{array}$ & $* * *$ & $\begin{array}{r}-0.037 \\
(0.010) \\
\end{array}$ & $* * *$ \\
\hline Foreign ownership & $\begin{array}{r}-0.018 \\
(0.017) \\
\end{array}$ & & $\begin{array}{r}-0.054 \\
(0.016) \\
\end{array}$ & $* * *$ & $\begin{array}{r}-0.012 \\
(0.010) \\
\end{array}$ & $\begin{array}{r}-0.031 \\
(0.018) \\
\end{array}$ & $*$ & $\begin{array}{r}-0.015 \\
(0.013) \\
\end{array}$ & & $\begin{array}{r}-0.038 \\
(0.018) \\
\end{array}$ & $* *$ \\
\hline Share of exports in sales & $\begin{array}{r}0.005 \\
(0.001) \\
\end{array}$ & $* * *$ & $\begin{array}{r}0.003 \\
(0.001) \\
\end{array}$ & $* * *$ & $\begin{array}{rl}0.002 & * * * \\
(0.000) & \\
\end{array}$ & $\begin{array}{r}0.005 \\
(0.001) \\
\end{array}$ & $* * *$ & $\begin{array}{r}0.002 \\
(0.001) \\
\end{array}$ & $* * *$ & $\begin{array}{r}0.005 \\
(0.001) \\
\end{array}$ & $* * *$ \\
\hline Share of exports in sales squared & $\begin{array}{r}0.000 \\
(0.000) \\
\end{array}$ & $* * *$ & $\begin{array}{r}0.000 \\
(0.000) \\
\end{array}$ & *** & $\begin{array}{rl}0.000 & * * * \\
(0.000) & \\
\end{array}$ & $\begin{array}{r}0.000 \\
(0.000) \\
\end{array}$ & $* * *$ & $\begin{array}{r}0.000 \\
(0.000) \\
\end{array}$ & $* * *$ & $\begin{array}{r}0.000 \\
(0.000) \\
\end{array}$ & $* * *$ \\
\hline Share of expansion-investment & $\begin{array}{r}0.001 \\
(0.000) \\
\end{array}$ & $* * *$ & $\begin{array}{r}0.001 \\
(0.000) \\
\end{array}$ & $* * *$ & $\begin{array}{r}0.000 \text { *** } \\
(0.000)\end{array}$ & $\begin{array}{r}0.001 \\
(0.000) \\
\end{array}$ & $* * *$ & $\begin{array}{r}0.001 \\
(0.000) \\
\end{array}$ & $* * *$ & $\begin{array}{r}0.001 \\
(0.000) \\
\end{array}$ & $* * *$ \\
\hline Time dummies & yes & & yes & & yes & yes & & yes & & yes & \\
\hline Size dummies & yes & & yes & & yes & yes & & yes & & yes & \\
\hline Industry dummies & yes & & yes & & yes & yes & & yes & & yes & \\
\hline Pseudo-R ${ }^{2}$ & 0.170 & & 0.060 & & 0.120 & 0.160 & & 0.150 & & 0.160 & \\
\hline Number of establishments & 8,359 & & 8,361 & & 8,359 & 8,359 & & 8,357 & & 8,358 & \\
\hline Number of observations & 20,470 & & 20,478 & & 20,474 & 20,472 & & 20,460 & & 20,472 & \\
\hline
\end{tabular}

Notes: Clustered (by establishment) standard errors in parentheses. The model specification is given by equation (1) in the text. *,**, and ${ }^{* * *}$ denote statistical significance at the $0.1,0.05$, and 0.01 , levels, respectively. 
Table 5

Probit estimates of the determinants of innovation in Germany, all establishments with at least 5 employees in the private sector, 2007-2010

\begin{tabular}{|c|c|c|c|c|c|c|}
\hline \multirow{2}{*}{\multicolumn{7}{|c|}{\begin{tabular}{|l|c} 
& incremental \\
No sectoral agreement \& no works council (reference)
\end{tabular}}} \\
\hline & & & & & & \\
\hline No sectoral agreement \& works council & $\begin{array}{r}-0.060 \\
(-0.074)\end{array}$ & $\begin{array}{r}-0.009 \\
(-0.068) \\
\end{array}$ & $\begin{array}{r}-0.170 \\
(-0.081)\end{array}$ & $\begin{array}{r}-0.009 \\
(-0.074) \\
\end{array}$ & $\begin{array}{r}-0.028 \\
(-0.068) \\
\end{array}$ & $\begin{array}{r}0.036 \\
(0.076) \\
\end{array}$ \\
\hline Sectoral agreement \& no works council & $\begin{array}{r}-0.099 \\
(-0.044)\end{array}$ & $\begin{array}{r}-0.004 \\
(-0.044) \\
\end{array}$ & $\begin{array}{r}-0.088 \\
(-0.060) \\
\end{array}$ & \begin{tabular}{rr|}
-0.142 & $* * *$ \\
$(-0.043)$ & \\
\end{tabular} & $\begin{array}{rl}-0.087 & * * \\
(-0.049) & \\
\end{array}$ & $\begin{array}{rr}-0.094 & * * \\
(0.043) & \\
\end{array}$ \\
\hline Sectoral agreement \& works council & $\begin{array}{r}0.180 \\
(-0.062)\end{array}$ & $\begin{array}{r}-0.009 \\
(-0.058)\end{array}$ & $\begin{array}{r}-0.021 \\
(-0.069)\end{array}$ & $\begin{array}{r}0.095 \\
(-0.062)\end{array}$ & $\begin{array}{r}0.161 \\
(-0.059)\end{array}$ & $\begin{aligned} 0.144^{* *} \\
(0.062)\end{aligned}$ \\
\hline Firm-level agreement \& no works council & $\begin{array}{r}0.087 \\
(-0.088) \\
\end{array}$ & $\begin{array}{c}-0.112 \\
(-0.09)\end{array}$ & $\begin{array}{r}-0.050 \\
(-0.117) \\
\end{array}$ & $\begin{array}{r}0.022 \\
(-0.087) \\
\end{array}$ & $\begin{array}{r}-0.015 \\
(-0.095) \\
\end{array}$ & $\begin{array}{r}-0.045 \\
(0.087) \\
\end{array}$ \\
\hline Firm-level agreement \& works council & $\begin{array}{r}-0.045 \\
(-0.085)\end{array}$ & $\begin{array}{r}-0.025 \\
(-0.079) \\
\end{array}$ & $\begin{array}{rl}-0.295 & * * * \\
(-0.097) & \\
\end{array}$ & $\begin{array}{r}-0.039 \\
(-0.086)\end{array}$ & $\begin{array}{r}-0.080 \\
(-0.079)\end{array}$ & $\begin{array}{r}-0.107 \\
(0.086)\end{array}$ \\
\hline \multicolumn{7}{|l|}{ No R\&D (reference) } \\
\hline R\&D in establishment & $\begin{array}{r}1.063 \\
(-0.054)\end{array}$ & $\begin{array}{rl}0.347 & * * * \\
(-0.048) & \\
\end{array}$ & $\begin{array}{rl}0.717 & * * * \\
(-0.055) & \\
\end{array}$ & $\begin{array}{rl}0.532 & * * * \\
(-0.056) & \\
\end{array}$ & $\begin{array}{r}1.028 \\
(-0.047)\end{array}$ & $\begin{array}{rr}1.028 & * * * \\
(0.057) & \\
\end{array}$ \\
\hline R\&D in enterprise & $\begin{array}{r}0.176 \\
(-0.095)\end{array}$ & $\begin{array}{r}0.008 \\
(-0.091) \\
\end{array}$ & $\begin{array}{rl}0.345 & * * * \\
(-0.105) & \\
\end{array}$ & $\begin{array}{r}0.199 \\
(-0.096)\end{array}$ & $\begin{array}{r}0.145 \\
(-0.092) \\
\end{array}$ & $\begin{array}{r}0.158 \\
(0.097) \\
\end{array}$ \\
\hline Individually owned & $\begin{array}{rl}-0.127 & * * \\
(-0.052) & \end{array}$ & $\begin{array}{r}-0.063 \\
(-0.052)\end{array}$ & $\begin{array}{r}-0.122 \\
(-0.070)\end{array}$ & $\begin{array}{rl}-0.147 & * * \\
(-0.051) & \end{array}$ & $\begin{array}{r}-0.088 \\
-0.058)\end{array}$ & $\begin{array}{r}-0.083 \\
(0.051)\end{array}$ \\
\hline Further training & $\begin{array}{r}0.2655^{* * *} \\
(-0.034)\end{array}$ & $\begin{array}{r}0.200 \\
(-0.035)\end{array}$ & $\begin{array}{r}0.208 \\
(-0.047)\end{array}$ & \begin{tabular}{rr|}
0.219 & $* * *$ \\
$(-0.034)$ & \\
\end{tabular} & $\begin{array}{r}0.280 \\
(-0.038)\end{array}$ & $\begin{array}{r}0.271 \\
(0.034)\end{array}$ \\
\hline \multicolumn{7}{|c|}{ Expected business volume development: increase (reference). } \\
\hline $\begin{array}{l}\text { Expected business volume development: } \\
\text { constant }\end{array}$ & $\begin{array}{r}-0.1722^{* * *} \\
(-0.032)\end{array}$ & $\begin{array}{r}-0.112 \\
(-0.031)\end{array}$ & $\begin{array}{r}-0.067 * \\
(-0.040)\end{array}$ & $\begin{array}{r}-0.123 \\
(-0.032)\end{array}$ & $\begin{array}{rl}-0.187 & * * * \\
(-0.033) & \end{array}$ & $\begin{array}{rl}-0.190 & * * * \\
(0.032) & \end{array}$ \\
\hline $\begin{array}{l}\text { Expected business volume development: } \\
\text { decrease }\end{array}$ & $\begin{array}{rl}-0.187 & * * * \\
(-0.038) & \end{array}$ & $\begin{array}{r}-0.071 \\
(-0.037)\end{array}$ & $\begin{array}{r}-0.073 \\
(-0.049)\end{array}$ & $\begin{array}{r}-0.049 \\
(-0.038)\end{array}$ & $\begin{array}{r}-0.184 \\
(-0.040)\end{array}$ & $\begin{array}{rl}-0.148 & * * * \\
(0.038) & \end{array}$ \\
\hline \multicolumn{7}{|c|}{ State of the technical equipment: state-of-the-art (reference) } \\
\hline $\begin{array}{l}\text { State of the technical equipment: rather } \\
\text { new }\end{array}$ & $\begin{array}{rl}-0.080 & * * \\
(-0.038) & \end{array}$ & $\begin{array}{r}-0.067 * \\
(-0.036)\end{array}$ & $\begin{array}{r}-0.114 \\
(-0.045)\end{array}$ & $\begin{array}{rl}-0.242 & * * * \\
(-0.038) & \end{array}$ & $\begin{array}{r}-0.047 \\
(-0.038)\end{array}$ & $\begin{aligned}-0.073 * \\
(0.038)\end{aligned}$ \\
\hline State of the technical equipment: medium & $-0.233 * * *$ & $-0.146^{* * *}$ & $-0.224 * * *$ & $-0.357 \quad * * *$ & $-0.170 \quad * * *$ & $-0.187 * * *$ \\
\hline
\end{tabular}




\begin{tabular}{|c|c|c|c|c|c|c|}
\hline or worse & $(-0.045)$ & $(-0.043)$ & $(-0.055)$ & $(-0.044)$ & $(-0.045)$ & $(0.044)$ \\
\hline Share of part-time workers & $\begin{array}{r}-0.001 \\
(-0.001) \\
\end{array}$ & $\begin{array}{rl}0.002 & * * * \\
(-0.001) & \\
\end{array}$ & $\begin{array}{r}0.002 \\
(-0.001) \\
\end{array}$ & $\begin{array}{r}-0.001 \\
(-0.001) \\
\end{array}$ & $\begin{array}{r}0.000 \\
(-0.001) \\
\end{array}$ & $\begin{array}{r}0.000 \\
(0.001) \\
\end{array}$ \\
\hline Share of fixed-term contract workers & $\begin{array}{r}0.001 \\
(-0.001) \\
\end{array}$ & $\begin{array}{r}0.000 \\
(-0.001) \\
\end{array}$ & $\begin{array}{r}0.001 \\
(-0.002) \\
\end{array}$ & $\begin{array}{r}0.000 \\
(-0.001) \\
\end{array}$ & $\begin{array}{r}0.001 \\
(-0.001) \\
\end{array}$ & $\begin{array}{r}0.001 \\
(0.001) \\
\end{array}$ \\
\hline Share of high-skilled workers & $\begin{array}{rl}0.007 & * * * \\
(-0.001) & \end{array}$ & $\begin{array}{rl}0.003 & * * \\
(-0.001) & \\
\end{array}$ & $\begin{array}{rl}0.007 & * * * \\
(-0.001) & \end{array}$ & $\begin{array}{r}0.002 \\
(-0.001)\end{array}$ & $\begin{array}{r}0.006 \\
(-0.001)\end{array}$ & $\begin{array}{r}0.005 \\
(0.001)\end{array}$ \\
\hline Single-establishment & $\begin{array}{r}-0.103 \\
(-0.042)\end{array}$ & $\begin{array}{rl}-0.171 & * * * \\
(-0.039) & \end{array}$ & $\begin{array}{r}-0.092 \\
(-0.047)\end{array}$ & $\begin{array}{r}-0.1644^{* * *} \\
(-0.042)\end{array}$ & $\begin{array}{rl}-0.124 & * * * \\
(-0.040) & \\
\end{array}$ & $\begin{array}{l}-0.121 \\
(0.042)\end{array}$ \\
\hline Foreign ownership & $\begin{array}{r}-0.038 \\
(-0.070) \\
\end{array}$ & $\begin{array}{rl}-0.235 & * * * \\
(-0.065) & \\
\end{array}$ & $\begin{array}{r}-0.052 \\
(-0.073) \\
\end{array}$ & $\begin{array}{r}-0.062 \\
(-0.071) \\
\end{array}$ & $\begin{array}{r}-0.102 \\
(-0.064) \\
\end{array}$ & $\begin{array}{r}-0.131 * \\
(0.072)\end{array}$ \\
\hline West-Germany & $\begin{array}{r}0.355 \\
(-0.039)\end{array}$ & $\begin{array}{r}0.022 \\
(-0.038) \\
\end{array}$ & $\begin{array}{r}0.031 \\
(-0.047) \\
\end{array}$ & $\begin{array}{rr}0.323 & * * * \\
(-0.039) & \\
\end{array}$ & $\begin{array}{rl}0.296 & * * * \\
(-0.040) & \\
\end{array}$ & $\begin{array}{rr}0.319 & * * * \\
(0.039) & \\
\end{array}$ \\
\hline Share of exports in sales & $\begin{array}{r}0.022 \\
(-0.003)\end{array}$ & $\begin{array}{rl}0.015 & * * * \\
(-0.003) & \\
\end{array}$ & $\begin{array}{rl}0.019 & * * * \\
(-0.003) & \\
\end{array}$ & $\begin{array}{rr}0.012 & * * * \\
(-0.003) & \\
\end{array}$ & $\begin{array}{rl}0.023 & * * * \\
(-0.003) & \\
\end{array}$ & $\begin{array}{rr}0.025 \\
(0.003)\end{array}$ \\
\hline Share of exports in sales squared & $\begin{array}{rl}0.000 & * * * \\
(0.000) & \\
\end{array}$ & $\begin{array}{rl}0.000 & * * * \\
(0.000) & \\
\end{array}$ & $\begin{array}{rr}0.000 & * * * \\
(0.000) & \\
\end{array}$ & $\begin{array}{rr}0.000 & * * * \\
(0.000) & \\
\end{array}$ & $\begin{array}{rr}0.000 & * * * \\
(0.000) & \\
\end{array}$ & $\begin{array}{r}0.000 \\
(0.000)\end{array}$ \\
\hline Share of expansion-investment & $\begin{array}{rl}0.004 & * * * \\
(0.000) & \\
\end{array}$ & $\begin{array}{rl}0.004 & * * * \\
(0.000) & \\
\end{array}$ & $\begin{array}{r}0.004 \quad * * * \\
(-0.001)\end{array}$ & $\begin{array}{rl}0.006 & * * * \\
(0.000) & \\
\end{array}$ & $\begin{array}{rl}0.005 & * * * \\
(0.000) & \\
\end{array}$ & $\begin{array}{r}0.005 \\
(0.000)\end{array}$ \\
\hline Time dummies & yes & yes & yes & yes & yes & yes \\
\hline Size dummies & yes & yes & yes & yes & yes & yes \\
\hline Industry dummies & yes & yes & yes & yes & yes & yes \\
\hline Rho & $\begin{array}{c}0.56^{* * *} \\
(0.01)\end{array}$ & $\begin{array}{c}0.52^{* * *} \\
(0.01)\end{array}$ & $\begin{array}{c}0.50^{* * *} \\
(0.02)\end{array}$ & $\begin{array}{c}0.55^{* * *} \\
(0.01)\end{array}$ & $\begin{array}{c}0.49 * * * \\
(0.01)\end{array}$ & $\begin{array}{c}0.55^{* * *} \\
(0.01)\end{array}$ \\
\hline Number of establishments & 8,359 & 8,361 & 8,359 & 8,359 & 8,357 & 8,358 \\
\hline Number of observations & 20,470 & 20,478 & 20,474 & 20,472 & 20,460 & 20,472 \\
\hline Pearson's r & 0.37 & 0.32 & 0.24 & 0.37 & 0.28 & 0.37 \\
\hline Joint probability. & 0.29 & 0.14 & 0.02 & 0.36 & 0.08 & 0.39 \\
\hline Marginal probability & 0.44 & 0.27 & 0.08 & 0.52 & 0.19 & 0.55 \\
\hline Odds ratio & 4.85 & 4.59 & 6.47 & 4.82 & 4.62 & 4.76 \\
\hline
\end{tabular}

Notes: Clustered (by establishment) standard errors in parentheses. The model specification is given by equation (2) in the text. *,**, and ${ }^{* * *}$ denote statistical significance at the $0.1,0.05$, and 0.01 , levels, respectively. 
Table 6

The difference-in-differences effect of joining/leaving sectoral collective bargaining agreements on the probability of any type of innovation in Germany, for innovating and non-innovating establishments with at least 5 employees, private sector, 2007-2010

\begin{tabular}{|c|c|c|c|}
\hline & & \multicolumn{2}{|c|}{ Treatment effect } \\
\hline Sample & Experiment & Probit model & $\begin{array}{c}\text { Linear probabilty } \\
\text { model }\end{array}$ \\
\hline \multirow{2}{*}{$\begin{array}{l}\text { Non-innovating } \\
\text { establishments without a } \\
\text { works council }\end{array}$} & $\begin{array}{l}\text { Scb joiners vs. scb never } \\
\text { members (Case 1) }\end{array}$ & $\begin{array}{l}0.04 \\
\left(\mathrm{~N}=426 ; \chi^{2}=35.51\right)\end{array}$ & $\begin{array}{l}0.03 \\
\left(N=426 ; R^{2}=0.08\right)\end{array}$ \\
\hline & $\begin{array}{l}\text { Scb leavers vs. scb } \\
\text { always members (Case 2) }\end{array}$ & $\begin{array}{l}-0.03 \\
\left(\mathrm{~N}=266 ; \chi^{2}=40.39^{* *}\right)\end{array}$ & $\begin{array}{l}-0.03 \\
\left(\mathrm{~N}=272 ; \mathrm{R}^{2}=0.17\right)\end{array}$ \\
\hline \multirow{2}{*}{$\begin{array}{l}\text { Non-innovating } \\
\text { establishments with a } \\
\text { works council }\end{array}$} & $\begin{array}{l}\text { Scb joiners vs. scb never } \\
\text { members (Case 1) }\end{array}$ & The sample is too small. & $\begin{array}{l}\text { The sample is too } \\
\text { small. }\end{array}$ \\
\hline & $\begin{array}{l}\text { Scb leavers vs. scb } \\
\text { always members (Case 2) }\end{array}$ & $\begin{array}{l}0.32 \\
\left(\mathrm{~N}=89 ; \chi^{2}=43.29 *\right)\end{array}$ & $\begin{array}{l}0.25 \\
\left(\mathrm{~N}=95 ; \mathrm{R}^{2}=0.42\right)\end{array}$ \\
\hline \multirow[t]{2}{*}{$\begin{array}{l}\text { Innovating establishment } \\
\text { without a works council }\end{array}$} & $\begin{array}{l}\text { Scb joiners vs. scb never } \\
\text { members (Case 3) }\end{array}$ & $\begin{array}{l}0.04 \\
\left(\mathrm{~N}=890 ; \chi^{2}=107.85^{* * *}\right)\end{array}$ & $\begin{array}{l}0.04 \\
\left(\mathrm{~N}=892 ; \mathrm{R}^{2}=0.10\right)\end{array}$ \\
\hline & $\begin{array}{l}\text { Scb leavers vs. scb } \\
\text { always members (Case 4) }\end{array}$ & $\begin{array}{l}-0.01 \\
\left(\mathrm{~N}=330 ; \chi^{2}=48.59^{* *}\right)\end{array}$ & $\begin{array}{l}-0.01 \\
\left(\mathrm{~N}=343 ; \mathrm{R}^{2}=0.17\right)\end{array}$ \\
\hline \multirow[t]{2}{*}{$\begin{array}{l}\text { Innovating establishment } \\
\text { with a works council }\end{array}$} & $\begin{array}{l}\text { Scb joiners vs. scb never } \\
\text { members (Case 3) }\end{array}$ & The sample is too small. & $\begin{array}{l}0.06 \\
\left(\mathrm{~N}=157 ; \mathrm{R}^{2}=0.23\right)\end{array}$ \\
\hline & $\begin{array}{l}\text { Scb leavers vs. scb } \\
\text { always members (Case 4) }\end{array}$ & $\begin{array}{l}-0.56^{*} \\
\left(\mathrm{~N}=360 ; \chi^{2}=60.32^{* * *}\right)\end{array}$ & $\begin{array}{l}-0.44^{* * *} \\
\left(\mathrm{~N}=444 ; \mathrm{R}^{2}=0.17\right)\end{array}$ \\
\hline
\end{tabular}

Notes: The treatment effect in the final two columns is given by the marginal effect obtained by running probit and linear probability models, respectively. Both the dependent variable - any type of innovation - and the treatment variable (i.e. sectoral collective bargaining agreement status) are dated in $t_{1}$. The control variables are in first differences. Establishments recording a change in works council status were excluded from the estimation sample. See Appendix Table C for full details on model implementation and interpretation. ${ }^{*}, * *$, and ${ }^{* * *}$ denote statistical significance at the $0.1,0.05$, and 0.01 , levels, respectively. 
Table 7

The difference-in-differences effect of joining/leaving sectoral collective bargaining agreements on the probability of any type of innovation in Germany, for innovating and non-innovating establishments with at least 5 employees, private sector, 2007-2010, with interaction dummies

\begin{tabular}{|c|c|c|c|c|}
\hline \multirow[b]{3}{*}{ Interaction terms } & \multicolumn{4}{|c|}{ Treatment effect } \\
\hline & \multicolumn{2}{|c|}{$\begin{array}{c}\text { Experiment: scb joiners vs. scb } \\
\text { never members }\end{array}$} & \multicolumn{2}{|c|}{$\begin{array}{c}\text { Experiment: scb leavers vs. scb } \\
\text { always members }\end{array}$} \\
\hline & $\begin{array}{l}\text { Sample: } \\
\text { Non-innovating } \\
\text { innovating }\end{array}$ & $\begin{array}{l}\text { Sample: } \\
\text { Innovating } \\
\text { establishments }\end{array}$ & $\begin{array}{l}\text { Sample: } \\
\text { Non-Innovating } \\
\text { establishments }\end{array}$ & $\begin{array}{l}\text { Sample: } \\
\text { Innovating } \\
\text { establishments }\end{array}$ \\
\hline scb never member-no woco (reference) & --- & --- & & \\
\hline scb never members-woco & -0.01 & 0.03 & & \\
\hline Scb joiner-no woco & 0.06 & 0.03 & & \\
\hline Scb joiner-woco & --- & --- & & \\
\hline Scb leaver-no woco (reference) & & & --- & --- \\
\hline Scb leaver-woco & & & $0.50 * * *$ & -0.15 \\
\hline scb always members-no woco & & & 0.03 & 0.01 \\
\hline scb always members-woco & & & 0.13 & 0.11 \\
\hline
\end{tabular}

Notes: See notes to Table 6. The scb joiner-woco term in the first block is missing due to the presence of perfect collinearity. Establishments recording a change in works council status were excluded from the estimation sample. 


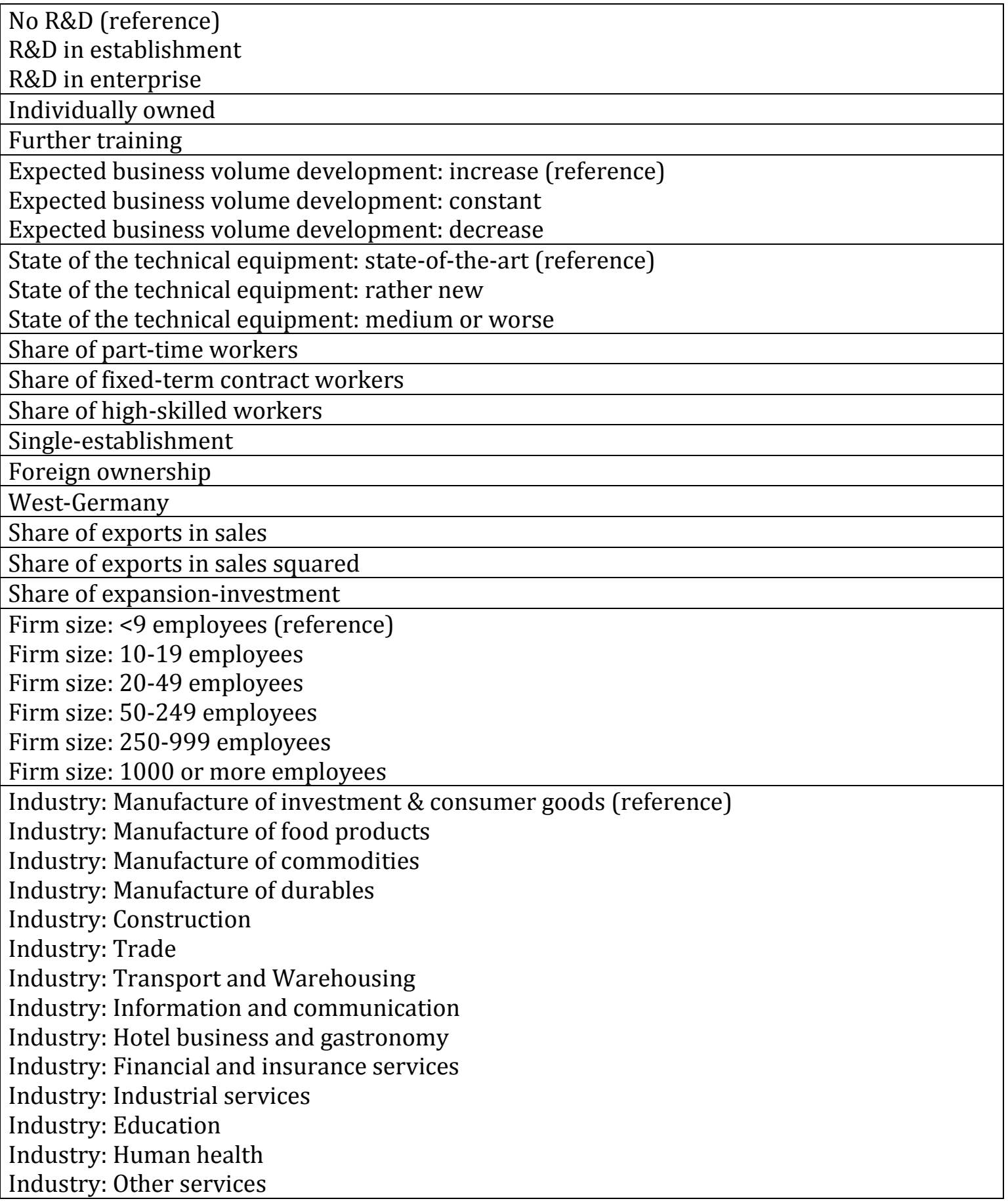


Appendix Table B

Sample innovation incidence in Germany by firm size, all establishments with at least five employees in the private sector, 2007-2010 (in percent)

\begin{tabular}{|c|c|c|c|c|c|c|}
\hline & \multicolumn{6}{|c|}{ Type of innovation } \\
\hline & incremental & imitation & radical & product & process & Any type \\
\hline \multicolumn{7}{|l|}{$<9$ employees } \\
\hline$P()$. & 33.1 & 20.7 & 6.2 & 39.6 & 12.4 & 41.1 \\
\hline$P(. \mid$ l_woco=0 $)$ & 32.3 & 19.1 & 5.5 & 38.5 & 11.4 & 40.0 \\
\hline$P(. \mid$ l_woco=1) & 36.3 & 27.4 & 8.1 & 44.4 & 12.9 & 45.2 \\
\hline $\mathrm{P}(. \mid 1$ _cb_status=scb) & 26.8 & 18.2 & 4.6 & 33.7 & 9.2 & 34.8 \\
\hline $\mathrm{P}\left(. \mid{ }_{1}\right.$ cb_status=fcb $)$ & 42.9 & 21.4 & 7.1 & 46.8 & 17.6 & 47.6 \\
\hline $\mathrm{P}(. \mid$ l_cb_status $=$ nocb $)$ & 34.4 & 19.7 & 6.0 & 40.5 & 12.0 & 42.2 \\
\hline \multicolumn{7}{|l|}{ 10-19 employees } \\
\hline$P()$. & 38.4 & 24.2 & 8.1 & 45.5 & 14.7 & 47.9 \\
\hline$P\left(. \mid 1 \_w o c o=0\right)$ & 36.5 & 22.9 & 7.3 & 43.5 & 13.2 & 45.6 \\
\hline$P(. \mid$ l_woco=1) & 43.2 & 25.4 & 7.6 & 50.7 & 17.7 & 54.8 \\
\hline $\mathrm{P}(. \mid 1$ _cb_status=scb) & 33.3 & 23.7 & 5.4 & 40.8 & 11.6 & 42.9 \\
\hline $\mathrm{P}\left(. \mid{ }_{\text {I_cb_status=fcb })}\right.$ & 42.5 & 27.0 & 8.5 & 49.5 & 17.0 & 52.5 \\
\hline $\mathrm{P}(. \mid$ l_cb_status=nocb) & 38.5 & 22.7 & 8.3 & 45.4 & 14.4 & 47.7 \\
\hline \multicolumn{7}{|l|}{ 20-49 employees } \\
\hline$P()$. & 43.8 & 27.4 & 9.9 & 51.8 & 19.6 & 54.0 \\
\hline$P\left(. \mid 1 \_w o c o=0\right)$ & 42.8 & 26.3 & 9.2 & 50.5 & 18.4 & 52.7 \\
\hline$P\left(. \mid 1 \_w o c o=1\right)$ & 45.9 & 27.4 & 9.9 & 53.4 & 20.1 & 55.5 \\
\hline $\mathrm{P}(. \mid 1$ _cb_status=scb) & 39.8 & 26.2 & 7.4 & 47.9 & 14.3 & 49.5 \\
\hline $\mathrm{P}\left(. \mid{ }_{\text {I_cb_status }=\mathrm{fcb})}\right.$ & 43.7 & 23.9 & 8.5 & 48.5 & 19.4 & 50.5 \\
\hline P(.|l_cb_status=nocb) & 45.5 & 27.1 & 10.6 & 53.2 & 21.3 & 55.7 \\
\hline \multicolumn{7}{|l|}{ 50-249 employees } \\
\hline$P()$. & 57.9 & 32.1 & 14.6 & 64.0 & 29.9 & 67.0 \\
\hline$P\left(. \mid 1 \_w o c o=0\right)$ & 53.0 & 30.6 & 13.9 & 58.9 & 26.0 & 61.7 \\
\hline$P\left(. \mid 1 \_w o c o=1\right)$ & 61.3 & 32.0 & 14.3 & 67.1 & 31.7 & 69.9 \\
\hline $\mathrm{P}\left(. \mid{ }_{\text {I_cb_status}=s c b)}\right.$ & 53.1 & 29.4 & 12.5 & 59.4 & 26.7 & 62.2 \\
\hline $\mathrm{P}\left(. \mid{ }_{1}\right.$ cb_status=fcb $)$ & 60.6 & 31.5 & 11.9 & 65.2 & 30.3 & 67.7 \\
\hline P(.|l_cb_status=nocb) & 60.3 & 33.3 & 16.3 & 66.1 & 30.6 & 69.0 \\
\hline \multicolumn{7}{|l|}{ 250-999 employees } \\
\hline $\mathrm{P}()$. & 76.1 & 40.2 & 20.2 & 79.3 & 46.8 & 81.7 \\
\hline$P\left(. \mid 1 \_w o c o=0\right)$ & 63.3 & 41.5 & 20.5 & 66.9 & 39.7 & 70.9 \\
\hline$P\left(. \mid 1 \_w o c o=1\right)$ & 78.2 & 39.5 & 19.7 & 81.1 & 47.0 & 83.2 \\
\hline $\mathrm{P}\left(. \mid l \_c b\right.$ status=scb $)$ & 76.9 & 37.1 & 19.4 & 78.6 & 47.3 & 80.7 \\
\hline $\mathrm{P}\left(. \mid{ }_{\text {I_cb_status}=f(b)}\right)$ & 74.9 & 38.6 & 17.7 & 77.9 & 43.8 & 79.7 \\
\hline P(.|l_cb_status=nocb) & 74.7 & 46.9 & 21.9 & 81.0 & 44.3 & 84.3 \\
\hline \multicolumn{7}{|l|}{1000 or mor employees } \\
\hline$P()$. & 86.2 & 45.3 & 32.7 & 87.5 & 69.2 & 89.2 \\
\hline$P\left(. \mid 1 \_w o c o=0\right)$ & 64.3 & 31.0 & 21.4 & 66.7 & 38.1 & 66.7 \\
\hline$P\left(. \mid 1 \_w o c o=1\right)$ & 87.4 & 46.3 & 33.6 & 88.5 & 70.4 & 90.1 \\
\hline$P\left(. \mid l \_c b \_s t a t u s=s c b\right)$ & 86.8 & 44.3 & 32.4 & 87.7 & 68.3 & 88.9 \\
\hline$P\left(. \mid l \_c b \_s t a t u s=f c b\right)$ & 83.3 & 42.7 & 32.1 & 84.5 & 75.0 & 88.2 \\
\hline $\mathrm{P}(. \mid$ l_cb_status=nocb) & 82.5 & 59.7 & 36.8 & 86.0 & 59.7 & 87.7 \\
\hline
\end{tabular}

Note: See notes to Table 2. 
Appendix Table C

The selection of subsamples

\begin{tabular}{|c|c|c|c|c|}
\hline & $\begin{array}{l}\text { Subsample } \\
\text { [Given by the } \\
\text { sectoral bargaining } \\
\text { and innovation } \\
\text { status in t0 (i.e. } \\
\text { 2007-2008)] }\end{array}$ & $\begin{array}{l}\text { Sectoral } \\
\text { bargaining } \\
\text { status in } t 1 \text { [i.e. } \\
2009-2010 \text { ] }\end{array}$ & $\begin{array}{l}\text { Outcome } \\
\text { Innovation in } \\
\text { t1 [i.e. 2009- } \\
\text { 2010] }\end{array}$ & $\begin{array}{l}\text { Interpretation } \\
\text { A positive } \\
\text { coefficient on the } \\
\text { scb variable } \\
\text { means that: }\end{array}$ \\
\hline Case 1 & $\begin{array}{l}\text { Establishments that } \\
\text { are both non- } \\
\text { innovators and not } \\
\text { covered by a sectoral } \\
\text { agreement; that is, } \\
\text { Innov }=0 \text { in both } \\
2007 \text { and } 2008 \\
\text { scb }=0 \text { in both } 2007 \\
\text { and } 2008\end{array}$ & $\begin{array}{l}1 / 0 \text { dummy } \\
(1 \text { if } s c b=1 \text { in } \\
\text { both } 2009 \text { and } \\
2010) ; 0 \text { if } \\
\text { scb=0 in both } \\
2009 \text { and } \\
2010)\end{array}$ & $\begin{array}{l}1 / 0 \text { dummy } \\
(1 \text { if Innov=1 in } \\
\text { either } 2009 \\
\text { and } 2010 \text {, or in } \\
\text { both; } 0 \\
\text { otherwise) }\end{array}$ & $\begin{array}{l}\text { Joining a sectoral } \\
\text { agreement } \\
\text { increases the } \\
\text { probability of } \\
\text { innovation for } \\
\text { plant without any } \\
\text { innovation at all in } \\
\text { t0 }\end{array}$ \\
\hline Case 2 & $\begin{array}{l}\text { Establishments that } \\
\text { are both non- } \\
\text { innovators and } \\
\text { covered by a sectoral } \\
\text { agreement; that is, } \\
\text { Innov } 0 \text { in both } \\
2007 \text { and } 2008 \\
\text { scb }=1 \text { in both } 2007 \\
\text { and } 2008\end{array}$ & $\begin{array}{l}1 / 0 \text { dummy } \\
(1 \text { if } s c b=0 \text { in } \\
\text { both } 2009 \text { and } \\
2010) ; 0 \text { if } \\
\text { scb=1 in both } \\
2009 \text { and } \\
2010)\end{array}$ & $\begin{array}{l}1 / 0 \text { dummy } \\
(1 \text { if Innov=1 in } \\
\text { either } 2009 \\
\text { and } 2010 \text {, or in } \\
\text { both years; } 0 \\
\text { otherwise) }\end{array}$ & $\begin{array}{l}\text { Leaving sectoral } \\
\text { agreement } \\
\text { decreases the } \\
\text { probability of } \\
\text { innovation for } \\
\text { plant without any } \\
\text { innovation at all in } \\
\text { t0 }\end{array}$ \\
\hline Case 3 & $\begin{array}{l}\text { Establishments that } \\
\text { are both innovators } \\
\text { and not covered by a } \\
\text { sectoral agreement; } \\
\text { that is, } \\
\text { Innov=1 in either } \\
2007 \text { and } 2008 \text { (or } \\
\text { in both) } \\
\text { scb=0 in both } 2007 \\
\text { and } 2008\end{array}$ & $\begin{array}{l}1 / 0 \text { dummy } \\
(1 \text { if } s c b=1 \text { in } \\
\text { both } 2009 \text { and } \\
2010) ; 0 \text { if } \\
\text { scb=0 in both } \\
2009 \text { and } \\
2010)\end{array}$ & $\begin{array}{l}1 / 0 \text { dummy } \\
(1 \text { if Innov=1 in } \\
\text { either } 2009 \\
\text { and } 2010 \text {, or in } \\
\text { both years; } 0 \\
\text { otherwise) }\end{array}$ & $\begin{array}{l}\text { Joining a sectoral } \\
\text { agreement } \\
\text { increases the } \\
\text { probability of } \\
\text { innovation for } \\
\text { plant with some } \\
\text { innovation in t0 }\end{array}$ \\
\hline Case 4 & $\begin{array}{l}\text { Establishments that } \\
\text { are both innovators } \\
\text { and covered by a } \\
\text { sectoral agreement, } \\
\text { that is, } \\
\text { Innov=1 in either } \\
2007 \text { and } 2008 \text { (or } \\
\text { in both years) } \\
\text { scb=1 in both } 2007 \\
\text { and } 2008\end{array}$ & $\begin{array}{l}1 / 0 \text { dummy } \\
(1 \text { if } s c b=0 \text { in } \\
\text { both } 2009 \text { and } \\
2010) ; 0 \text { if } \\
\text { scb=1 in both } \\
2009 \text { and } \\
2010)\end{array}$ & $\begin{array}{l}1 / 0 \text { dummy } \\
(1 \text { if Innov=1 in } \\
\text { either } 2009 \\
\text { and } 2010 \text {, or in } \\
\text { both years; } 0 \\
\text { otherwise) }\end{array}$ & $\begin{array}{l}\text { Leaving sectoral } \\
\text { agreement } \\
\text { increases the } \\
\text { probability of } \\
\text { innovation for } \\
\text { plant with some } \\
\text { innovation in t0 }\end{array}$ \\
\hline
\end{tabular}


Appendix Table D

The difference-in-differences effect of joining/leaving sectoral collective bargaining agreements on the probability of any type of innovation in Germany, for innovating and non-innovating establishments with at least 5 employees, private sector, 2007-2010

\begin{tabular}{|l|l|l|l|}
\hline \multicolumn{2}{|c|}{} & $\begin{array}{c}\text { Without a works council } \\
\text { dummy }\end{array}$ & \multicolumn{1}{c|}{$\begin{array}{c}\text { With a works council } \\
\text { dummy }\end{array}$} \\
\hline \multirow{4}{*}{$\begin{array}{l}\text { Non-innovating } \\
\text { establishments }\end{array}$} & $\begin{array}{l}\text { Scb joiners vs } \\
\text { scb never members }\end{array}$ & $\begin{array}{l}0.06 \\
\left(\mathrm{~N}=467 ; \chi^{2}=35.15\right)\end{array}$ & $\begin{array}{c}0.06 \\
\left(\mathrm{~N}=467 ; \chi^{2}=35.15\right.\end{array}$ \\
\cline { 2 - 4 } & $\begin{array}{l}\text { Scb leaver vs } \\
\text { scb always members }\end{array}$ & $\begin{array}{l}0.04 \\
\left(\mathrm{~N}=365 ; \chi^{2}=59.92^{* * *}\right)\end{array}$ & $\begin{array}{l}0.05 \\
\left(\mathrm{~N}=365 ; \chi^{2}=62.02^{* * *}\right)\end{array}$ \\
\hline \multirow{3}{*}{$\begin{array}{l}\text { Innovating } \\
\text { establishments }\end{array}$} & $\begin{array}{l}\text { Scb joiners vs } \\
\text { scb never members }\end{array}$ & $\begin{array}{l}0.03 \\
(\mathrm{~N}=1053 ; \\
\left.\chi^{2}=132.03^{* * *}\right)\end{array}$ & $\begin{array}{l}0.03 \\
(\mathrm{~N}=1052 ; \\
\left.\chi^{2}=132.79^{* * *}\right)\end{array}$ \\
\cline { 2 - 4 } & $\begin{array}{l}\text { Scb leavers vs } \\
\text { scb always members }\end{array}$ & $\begin{array}{l}-0.07 \\
\left(\mathrm{~N}=735 ; \chi^{2}=112.63^{* * *}\right)\end{array}$ & $\begin{array}{l}-0.05 \\
\left(\mathrm{~N}=735 ; \chi^{2}=117.91^{* * *}\right)\end{array}$ \\
\hline
\end{tabular}

Notes: In the first row of the table we have scb joiners vs. scb never members (or Case 1 in Appendix Table C), while in the second, third, and fourth rows we have Cases 2, 3, and 4, respectively. Establishments recording a change in works council status were excluded from the estimation sample. ${ }^{*}, * *$, and ${ }^{* * *}$ denote statistical significance at the $0.1,0.05$, and 0.01 , levels. 